Review

\title{
Antimicrobial Activity of Zinc Oxide Nano/Microparticles and Their Combinations against Pathogenic Microorganisms for Biomedical Applications: From Physicochemical Characteristics to Pharmacological Aspects
}

\author{
Su-Eon Jin $1, *$ (i) and Hyo-Eon Jin ${ }^{2, *(1)}$ \\ 1 Research Institute for Medical Sciences, College of Medicine, Inha University, Incheon 22212, Korea \\ 2 College of Pharmacy, Ajou University, Suwon 16499, Korea \\ * Correspondence: jins@inha.ac.kr (S.-E.J.); hjin@ajou.ac.kr (H.-E.J.)
}

check for updates

Citation: Jin, S.-E.; Jin, H.-E. Antimicrobial Activity of Zinc Oxide Nano/Microparticles and Their Combinations against Pathogenic Microorganisms for Biomedical Applications: From Physicochemical Characteristics to Pharmacological Aspects. Nanomaterials 2021, 11, 263. https: / / doi.org/10.3390/nano110 20263

Academic Editor: Nghia P. Truong Received: 13 December 2020

Accepted: 17 January 2021

Published: 20 January 2021

Publisher's Note: MDPI stays neutral with regard to jurisdictional claims in published maps and institutional affiliations.

Copyright: (c) 2021 by the authors. Licensee MDPI, Basel, Switzerland. This article is an open access article distributed under the terms and conditions of the Creative Commons Attribution (CC BY) license (https:/ / creativecommons.org/licenses/by/ $4.0 /)$.

\begin{abstract}
Zinc oxide (ZnO) nano/microparticles (NPs/MPs) have been studied as antibiotics to enhance antimicrobial activity against pathogenic bacteria and viruses with or without antibiotic resistance. They have unique physicochemical characteristics that can affect biological and toxicological responses in microorganisms. Metal ion release, particle adsorption, and reactive oxygen species generation are the main mechanisms underlying their antimicrobial action. In this review, we describe the physicochemical characteristics of ZnO NPs/MPs related to biological and toxicological effects and discuss the recent findings of the antimicrobial activity of ZnO NPs/MPs and their combinations with other materials against pathogenic microorganisms. Current biomedical applications of $\mathrm{ZnO}$ NPs/MPs and combinations with other materials are also presented. This review will provide the better understanding of ZnO NPs/MPs as antibiotic alternatives and aid in further development of antibiotic agents for industrial and clinical applications.
\end{abstract}

Keywords: zinc oxide nano/microparticles; antimicrobial activity; nanoantibiotics; physicochemical characteristics; biomedical application

\section{Introduction}

Zinc oxide $(\mathrm{ZnO})$ nanoparticles (NPs) have been studied for the development of next-generation nanoantibiotics against pathogenic microorganisms to combat multi-drug resistance [1,2]. These nanoparticles show unique physicochemical properties including morphology, particle size, crystallinity, and porosity [3]. Based on these characteristics, $\mathrm{ZnO}$ NPs have a wide spectrum of antimicrobial activity against microorganisms including Escherichia coli, Staphylococcus aureus, Pseudomonas aeruginosa, Bacillus subtilis, and the M13 bacteriophage [4-7]. They can be combined with antibiotic and anti-inflammatory drugs to enhance antimicrobial activity against pathogenic microorganisms without antibiotic resistance in non-clinical and clinical conditions [7,8]. Use of ZnO NPs as well as microparticles (MPs) has been extended to biomedical applications including antibiotic drugs or medical devices, theranostics, implants, and cosmetics for conventional uses in clinics [9-12].

The physicochemical characterization of ZnO NPs/MPs offers advantageous information regarding biological or biochemical responses to pathogenic microorganisms, enabling the prediction of antimicrobial and toxicological effects [13,14]. Generally, their properties, including morphology, particle size or particle size distribution, porosity, and specific surface area, can affect antimicrobial responses $[14,15]$. ZnO NPs/MPs of various shapes such as spheres, rods, needles, and platelets, and their average aspect ratios (defined as ratio of length to width) can influence the antimicrobial actions against microorganisms. Their particle size and particle size distribution levels are the key parameters that determine NP uptake into biomembranes and thereby influence antimicrobial activity against pathogenic microorganisms [16,17]. Intra- and interparticle pores of ZnO NPs/MPs also enhance 
photocatalytic antimicrobial interactions under ultraviolet (UV) and visible light irradiation based on reactive oxygen species (ROS) [5,18]. Furthermore, large specific surface area levels of ZnO NPs/MPs facilitate membrane adsorption for antimicrobial actions [19].

Furthermore, combinations of ZnO NPs/MPs with other antibiotic drugs, metal oxide NPs/MPs, and devices have been used to enhance antimicrobial activity against pathogenic microorganisms [20-24]. They have synergistic or improved antimicrobial activity against E. coli, S. aureus, Aeromonas veronii, P. aeruginosa, B. subtilis, and Klebsiella pneumoniae. ZnO NP/MP combinations with other materials are applied as dosage forms other than particles, including membranes, films, and plates, according to the administration route or usage for enhanced antimicrobial performance [25-28]. These dosage forms can deliver the drug to the specific site of infection in human diseases including endocarditis, cystic fibrosis, pneumonia, and otitis [29,30].

In this review, we introduce the physicochemical characteristics of ZnO NPs/MPs to explain their antimicrobial activity against pathogenic microorganisms. The antimicrobial activity of ZnO NPs/MPs and their combinations with other antimicrobial materials such as antibiotic and anti-inflammatory drugs, metal oxide NPs/MPs, and polymers is also described. Moreover, current biomedical applications of ZnO NPs/MPs are presented.

\section{Characteristics of $\mathrm{ZnO}$ Materials Based on Synthesis Techniques}

$\mathrm{ZnO}$ NPs $(81.38 \mathrm{~g} / \mathrm{mol},<100 \mathrm{~nm})$ are white odorless solid powders of hexagonal wurtzite crystals with various shapes including spheres for zero-dimensional (0D) structures, dumbbells, nanorods, nanotubes, and needles for one-dimensional (1D) structures, disks and platelets for two-dimensional (2D) structures, and flowers, stars and flakes for three-dimensional (3D) structures [6]. They have a wide band gap energy $(\sim 3.3 \mathrm{eV})$ which is similar to that of titanium dioxide $\left(\mathrm{TiO}_{2}\right) \mathrm{NPs}$. Compared to $\mathrm{ZnO}$ NPs, $\mathrm{ZnO}$ MPs are generally in the submicron range regarding their size.

The physicochemical properties of $\mathrm{ZnO}$ materials mainly affect their antimicrobial activity against pathogenic microorganisms and are critical parameters linked to pharmacological and toxicological responses [31,32]. Their morphology, particle size, and porosity are determined to confer the superior antimicrobial activity in pathogenic microorganisms [3]. These physicochemical properties of $\mathrm{ZnO}$ NPs/MPs are influenced by the synthesis techniques used for their preparation $[5,6,33]$.

\subsection{Synthesis Techniques of $\mathrm{ZnO}$ Materials}

The synthesis techniques used for ZnO NPs/MPs are generally categorized by physical, chemical, biological, and microfluidic methods [5,34]. Physical methods of arc plasma, thermal evaporation, physical vapor deposition, ultrasonic irradiation, and laser ablation simply produce chemically pure ZnO NPs/MPs. Wet chemical methods for the synthesis of ZnO NPs/MPs such as microemulsion, sol-gel, precipitation, hydrothermal and solvothermal methods are extensively used to generate the specific physicochemical characteristics, based on their simple and scalable bottom-up approaches [35,36]. Biological methods, so called "green synthesis", are promoted as ecofriendly synthesis techniques including microorganisms (bacteria, fungi, yeasts, algae, and phages), plant extracts, DNA, and proteins [5,37]. The biosynthesized ZnO NPs/MPs have comparable physicochemical characteristics to those of physically or chemically synthesized ZnO NPs/MPs. Moreover, microfluidic methods can offer high-value $\mathrm{ZnO}$ NP/MP products using modular architecture integration for sophisticated reactions [5,38], which enable ZnO NPs/MPs to have targeted physicochemical properties.

Meanwhile, various electrochemical processes for synthesis of $\mathrm{ZnO}$ NPs / MPs have been reported including electrodeposition [39,40], sacrificial anode electrolysis [41], and electrochemical deposition under oxidizing conditions (EDOC) [42,43]. Hybrid techniques of electrochemical-thermal processes were also reported in aqueous environment $[44,45]$. In electrodeposition, $\mathrm{ZnO}$ thin films can be produced controlling current density, applied potential, time, and electrolytic bath concentration as major operating parameters using zinc 
nitrate solution or zinc chloride solution as precursors [40]. This technique is advantageous to achieve simple and cost-effective outcomes in large-surfaced substrate, which produces various structures of nanoneedle-like, prism-like, porous, and continuous shapes with appropriate thickness [39]. On silicon, $\mathrm{ZnO}$ deposition occurred from nonaqueous solution of dimethyl sulfoxide (DMSO) containing zinc chloride and potassium chloride, which films of $1-3 \mu \mathrm{m}$ thick had pore channels $(20 \mathrm{~nm})$. Next, sacrificial anode electrolysis from two-electrode cells to thee-electrode cells along with potentiostatic control improves reproducibility of morphological dimension in ZnO NPs/MPs [41]. In the electrode-cell, metal ions are produced in anodic dissolution or added into electrochemical medium and cathodic reduction induces particle growth with tunable morphology. Near-spherical $\mathrm{ZnO}$ NPs $(<25 \mathrm{~nm})$ in an amorphous phase were produced using sacrificial anodic dissolution of pure zinc metal strip $\left(2 \times 6 \times 1 \mathrm{~cm}^{3}\right)$ controlling against platinum mesh as the cathode in electrolyte of $0.1 \mathrm{M}$ tetrabutlyammonium bromide solution and acetonitrile (4:1) [46]. In EDOC, sacrificial anodic oxidation, cathodic reduction, and oxidation processes were involved for the synthesis of spherical ZnO NPs $(9 \mathrm{~nm})$ [42]. Hybridizing electrochemical and thermal approaches, ZnO NPs/MPs were synthesized in aqueous sodium bicarbonate solution, generating zinc hydroxide species and further oxidized to $\mathrm{ZnO}$ in calcination process at $>300{ }^{\circ} \mathrm{C}[44,45]$. Specifically, anionic or cationic stabilizers can be used to tune physicochemical properties of ZnO NPs/MPs including morphology and particle size.

\subsection{Physicochemical Characteristics of $\mathrm{ZnO}$ Materials}

We introduce the physicochemical characteristics of ZnO NPs/MPs which antimicrobial functions have already been reported. Table 1 displays morphology, particle size, porosity, surface area, and synthesis technique of ZnO NPs/MPs with antimicrobial functions against pathogenic microorganisms. In general, high aspect ratio, small particle size, multilevel porosity, and large surface area of ZnO NPs/MPs can enhance antimicrobial performance, irrespective of synthesis techniques [3,5,14]. Chemically or biologically synthesized ZnO NPs/MPs have been extensively used to determine their antimicrobial activity against microorganisms, rather than microfluidically or electrochemically synthesized ZnO NPs/MPs, due to simplicity, reproducibility, and production scale, yield or rate for obtaining high-value $\mathrm{ZnO}$ NPs / MPs with required characteristics [5,6,8].

First, in the 0D structure of ZnO NPs/MPs, Raghupathi et al. [16] reported the manufacture of spherical ZnO NPs (12-307 nm) with slit-like pores (3.49-90.4 $\mathrm{m}^{2} / \mathrm{g}$ surface area) using solvothermal and room temperature syntheses. Using the solvothermal technique for ZnO NP synthesis, smaller ZnO NPs (12-25 nm) with larger surface area $\left(42.8-90.4 \mathrm{~m}^{2} / \mathrm{g}\right)$ were obtained, compared to ZnO NP synthesis at room temperature (30-307 nm; 3.49$35.6 \mathrm{~m}^{2} / \mathrm{g}$ surface area). Green synthesized spherical ZnO NPs were reported, using Catharanthus roseus leaf extract and zinc acetate dehydrate [47]. In spherical ZnO NP synthesis, controllable reaction factors were optimized for $\mathrm{pH} 12,30^{\circ} \mathrm{C}, 0.01 \mathrm{M}$ precursor metal ion, and $2 \mathrm{~h}$ of reaction time to achieve high-value ZnO NPs for enhanced antimicrobial performance. Using green synthesis and co-precipitation, sphere-shaped ZnO NPs (15-20 nm) were obtained reacting with Bambusa Vulgaris plant extract and zinc nitrate aqueous solution (0.5 mol/50 mL) [48]. Compared to Bambusa Vularis plant extract, Artabotrys Hexapetalu plant extract was used to synthesize mixed spherical and rod-like ZnO NPs (20-30 nm). In green synthesis using Sambucus ebulus leaf extract and $1 \mathrm{M}$ zinc acetate dihydrate, spherical $\mathrm{ZnO}$ NPs were also prepared at 25-30 nm for transmission electron microscopy (TEM) and $65 \pm 4 \mathrm{~nm}$ for dynamic light scattering [49]. Moreover, a self-assembled 3D network structure of spherical ZnO NPs $(48.3 \mathrm{~nm})$ on a solid plate was also analyzed, in which NPs were synthesized via sol-gel technique using an annealing process at $150{ }^{\circ} \mathrm{C}$ [18]. In the self-assembled ZnO NP network, mesopores at 5-6.25 nm and macropores at 2-6 $\mu \mathrm{m}$ were detected, conferring bimodal porosity for enhanced performance. Meanwhile, spherical nanostructured $\mathrm{ZnO}(63 \mathrm{~nm})$ manufactured by soft chemical synthesis using micrometric $\mathrm{ZnO}$ and urea in glycerol, generated NP clusters $(590 \mathrm{~nm}$ ) with mesopores of $34 \mathrm{~nm}$ and a $20.72 \mathrm{~m}^{2} / \mathrm{g}$ surface area [19]. 
In the 1D structure of $\mathrm{ZnO}$ NPs/MPs, Bala et al. [50] reported dumbbell-shaped $\mathrm{ZnO}$ NPs (190-250 $\mathrm{nm}$ in length and 50-60 $\mathrm{nm}$ in breadth), which were prepared via green synthesis by reacting with Hibiscus subdariffa leaf extract and zinc acetate in water. The morphology of $\mathrm{ZnO}$ NPs was modified depending on drying temperature. After particle precipitation, dumbbell-shaped $\mathrm{ZnO}$ NPs were generated with further heating at $100{ }^{\circ} \mathrm{C}$ for $4 \mathrm{~h}$. In contrast to the dumbbell-shaped ZnO NPs, sphere-shaped ZnO NPs (12-46 nm) resulted from drying at $60^{\circ} \mathrm{C}$. The submicron $\mathrm{ZnO}$ dumbbell structure was generated using a chemical bath deposition technique at low temperature $\left(80^{\circ} \mathrm{C}\right)$ [51]. The resulting $\mathrm{ZnO}$ dumbbells were 1-2 $\mu \mathrm{m}$ long, 200-300 nm wide at one end, and 250-400 nm wide at the other end.

Table 1. Physicochemical characteristics of zinc oxide $(\mathrm{ZnO})$ materials.

\begin{tabular}{|c|c|c|c|c|c|}
\hline Morphology & Particle Size & Porosity & $\begin{array}{c}\text { Surface Area } \\
\left(\mathrm{m}^{2} / \mathrm{g}\right)\end{array}$ & $\begin{array}{l}\text { Synthesis Method } \\
\text { (Precursor) }\end{array}$ & Refs. \\
\hline \multirow{5}{*}{ Spheres } & $12 \mathrm{~nm}, 25 \mathrm{~nm}$ & Slit-like pores & $90.4,42.8$ & $\begin{array}{l}\text { Solvothermal synthesis } \\
\text { using tetramethyl ammonium } \\
\text { hydroxide (TMAOH) (zinc } \\
\text { nitrate hexahydrate) }\end{array}$ & [16] \\
\hline & $62-94 \mathrm{~nm}$ & Not available & Not available & $\begin{array}{l}\text { Green synthesis using } \\
\text { Catharanthus roseus leaf } \\
\text { extract }(0.01 \mathrm{M} \text { zinc acetate } \\
\text { dehydrate) }\end{array}$ & [47] \\
\hline & $15-20 \mathrm{~nm}$ & Not available & Not available & $\begin{array}{l}\text { Green synthesis \& } \\
\text { co-precipitation using } \\
\text { Bambusa Vulgaris leaf extract } \\
(0.5 \mathrm{~mol} / 50 \mathrm{~mL} \text { zinc nitrate in } \\
\text { water })\end{array}$ & [48] \\
\hline & $\begin{array}{l}\text { 25-30 nm (TEM); } \\
65 \pm 4 \mathrm{~nm} \\
\text { (dynamic light } \\
\text { scattering) }\end{array}$ & Not available & Not available & $\begin{array}{l}\text { Green synthesis using } \\
\text { Sambucus ebulus leaf extract } \\
\text { (1 M zinc acetate dihydrate) }\end{array}$ & [49] \\
\hline & $12-46 \mathrm{~nm}$ & Not available & Not available & $\begin{array}{l}\text { Green synthesis using } \\
\text { Hibiscus subdariffa leaf } \\
\text { extract with further heating at } \\
60^{\circ} \mathrm{C} \text { for } 4 \mathrm{~h} \text { ( } 91 \mathrm{mM} \text { zinc } \\
\text { acetate in water) }\end{array}$ & [50] \\
\hline $\begin{array}{l}\text { Spheres in } \\
\text { self-assembled } \\
\text { network }\end{array}$ & $48.3 \mathrm{~nm}$ & $\begin{array}{l}\text { Mesopores, } \\
5-6.25 \mathrm{~nm} ; \\
\text { macropores, } \\
2-6 \mu \mathrm{m}\end{array}$ & Not available & $\begin{array}{l}\text { Sol-gel synthesis using } \\
\text { oleylamine with annealing } \\
\text { process at } 150{ }^{\circ} \mathrm{C} \text { (zinc } \\
\text { acetylacetonate dihydrate) }\end{array}$ & [18] \\
\hline $\begin{array}{l}\text { Spheres in NP } \\
\text { cluster }\end{array}$ & $\begin{array}{l}\text { NPs-63 nm; } \\
\text { cluster-590 nm }\end{array}$ & $34 \mathrm{~nm}$ & 20.72 & $\begin{array}{l}\text { Soft chemical synthesis } \\
\text { using urea }(3.6 \mathrm{~mol}) \text { and } \\
\text { glycerol }(3.6 \mathrm{~mol}) \\
\text { (micrometric } \mathrm{ZnO}, 6 \mathrm{wt} . \%)\end{array}$ & [19] \\
\hline
\end{tabular}


Table 1. Cont.

\begin{tabular}{|c|c|c|c|c|c|}
\hline Morphology & Particle Size & Porosity & $\begin{array}{l}\text { Surface Area } \\
\left(\mathrm{m}^{2} / \mathrm{g}\right)\end{array}$ & $\begin{array}{l}\text { Synthesis Method } \\
\text { (Precursor) }\end{array}$ & Refs. \\
\hline Dumbbells & $\begin{array}{l}\text { Length } \\
\text { 190-250 nm; } \\
\text { breadth } 50-60 \mathrm{~nm}\end{array}$ & Not available & Not available & $\begin{array}{l}\text { Green synthesis using } \\
\text { Hibiscus subdariffa leaf } \\
\text { extract, dried at } 100{ }^{\circ} \mathrm{C} \text { for } 4 \mathrm{~h} \\
(91 \mathrm{mM} \text { zinc acetate in water) }\end{array}$ & [50] \\
\hline \multirow{3}{*}{ Nanorods } & $\begin{array}{l}\text { Length } 523 \mathrm{~nm} \text {; } \\
\text { diameter } 47 \mathrm{~nm}\end{array}$ & Not available & 2.3 & $\begin{array}{l}\text { Sol-gel synthesis using } 1 \mathrm{M} \\
\text { hexamethyl tetraamine } \\
\text { (HMTA) at pH } 6.5 \text { ( } 1 \mathrm{M} \text { zinc } \\
\text { nitrate in water) }\end{array}$ & [52] \\
\hline & & & & & \\
\hline & $\begin{array}{c}\text { Length } \sim 2 \mu \mathrm{m} ; \\
\text { diameter } \sim 50 \mathrm{~nm}\end{array}$ & Not available & Not available & $\begin{array}{l}\text { Green synthesis using Egg } \\
\text { white albumen calcined at } \\
650{ }^{\circ} \mathrm{C}(1 \mathrm{mmol} / \mathrm{mL} \text { zinc } \\
\text { acetate dihydrate })\end{array}$ & [53] \\
\hline \multirow{2}{*}{$\begin{array}{l}\text { Hollow } \\
\text { nanotubes }\end{array}$} & Length $\sim 500 \mathrm{~nm}$ & $\begin{array}{c}53 \mathrm{~nm}\left(900{ }^{\circ} \mathrm{C}\right. \\
\text { annealing), } \\
114.6 \mathrm{~nm}\left(700{ }^{\circ} \mathrm{C}\right. \\
\text { annealing), } \\
255.4 \mathrm{~nm}\left(500{ }^{\circ} \mathrm{C}\right. \\
\text { annealing), } \\
278.6 \mathrm{~nm} \\
\text { (as-synthesized) }\end{array}$ & $\begin{array}{c}2.4\left(900^{\circ} \mathrm{C}\right. \\
\text { annealing), } 7.2 \\
\left(700^{\circ} \mathrm{C} \text { annealing), }\right. \\
16.7\left(500^{\circ} \mathrm{C}\right. \\
\text { annealing), } 17.8 \\
\text { (as-synthesized) }\end{array}$ & $\begin{array}{l}\text { - Hydrothermal synthesis } \\
\text { using } 0.25 \mathrm{mM} \text { polyvinyl } \\
\text { alcohol (PVA) at pH } 9 \text { with } \\
\text { annealing process at } \\
500-900{ }^{\circ} \mathrm{C} \text { ( } 14 \mathrm{mM} \text { zinc } \\
\text { acetate dihydrate) }\end{array}$ & [54] \\
\hline & $\begin{array}{l}\text { Length } \sim 5 \mu \mathrm{m} ; \\
\text { thickness } 59.5 \mathrm{~nm}\end{array}$ & $\begin{array}{l}\text { Internal diameter } \\
178.2 \mathrm{~nm}\end{array}$ & Not available & $\begin{array}{l}\text { Atomic layer deposition } \\
\text { (ALD) over electrospun } \\
\text { polyvinyl alcohol (PVA) } \\
\text { nanofibers (template) after } \\
\text { polymer removal through } \\
\text { calcination or hydrolysis } \\
\text { (diethyl zinc ( } \mathrm{Zn}(\mathrm{C} 2 \mathrm{H} 5) 2)\end{array}$ & [55] \\
\hline Needles & $\begin{array}{l}\text { Length } \sim 2 \mu \mathrm{m} ; \\
\text { diameter } 20-40 \mathrm{~nm}\end{array}$ & Not available & Not available & $\begin{array}{l}\text { Green synthesis using } \\
\text { Berberis aristata leaf extract, } \\
\text { adjusting } \mathrm{pH} \text { with } 1 \mathrm{M} \\
\text { sodium hydroxide }(\mathrm{NaOH}) \\
(0.1 \mathrm{M} \text { zinc acetate dihydrate) }\end{array}$ & [56] \\
\hline Disks & $41 \mathrm{~nm}$ & Not available & Not available & $\begin{array}{l}\text { Co-precipitation using } 2 \mathrm{M} \\
\text { sodium hydroxide in water at } \\
\text { room temperature ( } 1 \mathrm{mM} \text { zinc } \\
\text { acetate dihydrate) }\end{array}$ & [57] \\
\hline Platelets & $\begin{array}{l}14.7 \mathrm{~nm}, 17.5 \mathrm{~nm} ; \\
\text { hydrodynamic } \\
\text { environment- } \\
6.4 \mu \mathrm{m}, 5.0 \mu \mathrm{m}\end{array}$ & $17.3 \mathrm{~nm}, 11.6 \mathrm{~nm}$ & $39.0,46.9$ & $\begin{array}{l}\text { Not available (conventional } \\
\text { products) }\end{array}$ & [58] \\
\hline
\end{tabular}


Table 1. Cont.

\begin{tabular}{|c|c|c|c|c|c|}
\hline Morphology & Particle Size & Porosity & $\begin{array}{l}\text { Surface Area } \\
\left(\mathrm{m}^{2} / \mathrm{g}\right)\end{array}$ & $\begin{array}{l}\text { Synthesis Method } \\
\text { (Precursor) }\end{array}$ & Refs. \\
\hline \multirow{4}{*}{ Flowers } & $\begin{array}{l}\text { Length } \\
\text { 200-500 nm; length } \\
1-2 \mu \mathrm{m}\end{array}$ & Not available & Not available & $\begin{array}{l}\text { Electrochemical-thermal } \\
\text { technique using poly-diallyl- } \\
\text { (dimethylammonium) } \\
\text { chloride (PDDA) and } \\
\text { benzyl-dimethylammonium } \\
\text { chloride (BAC) as a stabilizer } \\
\text { (Two Zn electrodes) }\end{array}$ & [45] \\
\hline & $23.7-88.8 \mathrm{~nm}$ & Not available & Not available & $\begin{array}{l}\text { Sol-gel synthesis using } \\
0.2 w / v \% \text { cetyltrimethyl } \\
\text { ammonium bromide (CTAB) } \\
\text { at } \mathrm{pH} 11.7-11.9 \text {, and } \\
\text { near-room temperatures } \\
\left(25-75^{\circ} \mathrm{C}\right)(5 \% \text { zinc acetate } \\
\text { dihydrate) }\end{array}$ & [59] \\
\hline & $700 \mathrm{~nm}-2.2 \mu \mathrm{m}$ & Not available & Not available & $\begin{array}{l}\text { Co-precipitation using } \\
0.1 \mathrm{M} \mathrm{NaOH} \text { calcined at } \\
550{ }^{\circ} \mathrm{C}(0.1 \mathrm{M} \text { zinc nitrate } \\
\text { hexahydrate })\end{array}$ & {$[60]$} \\
\hline & $45 \mathrm{~nm}$ & Not available & 28.8 & $\begin{array}{l}\text { Solvothermal synthesis } \\
\text { using } 0.5 \mathrm{M} \mathrm{NaOH} \text { at } \mathrm{pH} 9 \\
\text { ( } 5.60 \mathrm{~g} / 50 \mathrm{~mL} \text { zinc acetate } \\
\text { dihydrate in water) }\end{array}$ & [61] \\
\hline Stars & $31 \mathrm{~nm}$ & Not available & Not available & $\begin{array}{l}\text { Liquid precipitation using } \\
1 \mathrm{M} \mathrm{NaOH}(0.01 \mathrm{~mol} / 50 \mathrm{~mL} \\
\text { zinc acetate dihydrate in } \\
\text { water) }\end{array}$ & [62] \\
\hline Flakes & $32 \mathrm{~nm}$ & Not available & Not available & $\begin{array}{l}\text { Co-precipitation using } \\
0.02 \mathrm{M} \text { sodium carbonate } \\
(0.01 \mathrm{M} \text { zinc acetate })\end{array}$ & [63] \\
\hline
\end{tabular}

$\mathrm{ZnO}$ nanorods (523 $\mathrm{nm}$ in length and $47 \mathrm{~nm}$ in diameter) were reported as photocatalytic antibacterial agents by Singh et al. [52]. They were synthesized using the sol-gel technique by reacting with $1 \mathrm{M}$ zinc nitrate and $1 \mathrm{M}$ hexamethyl tetraamine (HMTA) at $\mathrm{pH}$ 6.5. Reactions carried out at $\mathrm{pH}$ 5.0-6.5 in mediated smaller $\mathrm{ZnO}$ nanorods. Using the green synthesis technique of reacting with egg white albumen and zinc acetate dihydrate in water $(1 \mathrm{mmol} / \mathrm{mL})$, the resulting $\mathrm{ZnO}$ nanorods had a highly crystalline structure at $\sim 2 \mu \mathrm{m}$ in length and $\sim 50 \mathrm{~nm}$ in diameter for enhanced antimicrobial performance [53]. Calcined temperature was determined as a controllable parameter for high-value $\mathrm{ZnO}$ nanorod synthesis, ranged at $400-650{ }^{\circ} \mathrm{C}$. $\mathrm{ZnO}$ nanorods calcined at the highest temperature $\left(650{ }^{\circ} \mathrm{C}\right)$ displayed pure and highly crystalline products.

Hollow $\mathrm{ZnO}$ nanotubes in nanopowders, ranging at $\sim 500 \mathrm{~nm}$ were manufactured via hydrothermal synthesis using polyvinyl alcohol (PVA) with a further annealing process at 500-900 ${ }^{\circ} \mathrm{C}$ [54]. After annealing, the surface area and pore size of the $\mathrm{ZnO}$ nanopowders were reduced from $17.8 \mathrm{~m}^{2} / \mathrm{g}$ and $278.6 \mathrm{~nm}$ to $2.4-16.7 \mathrm{~m}^{2} / \mathrm{g}$ and 53-255.4 $\mathrm{nm}$, respectively, 
compared to as-synthesized nanopowders, owing to sintering and growing boundaries to form microscale aggregates. Lopez de Dicastillo et al. [55] described hollow $\mathrm{ZnO}$ nanotubes $5 \mu \mathrm{m}$ in length and $59.5 \mathrm{~nm}$ in thickness with an internal diameter of $178.2 \mathrm{~nm}$, prepared via template methods using electrospun PVA nanofibers through atomic layer deposition of ZnO NPs from water and diethyl zinc. Thermal treatment or hydrolysis was additionally performed to remove the PVA template from the hollow ZnO nanotubes. Besides the nanotubes, $\mathrm{ZnO}$ needles were also reported as antimicrobial agents for urinary tract pathogens [56]. These needle-shaped ZnO NPs were green synthesized using Berberis aristata leaf extract and $0.1 \mathrm{M}$ zinc acetate dihydrate adjusting $\mathrm{pH}$ with $1 \mathrm{M}$ sodium hydroxide. Their size range was $\sim 2 \mu \mathrm{m}$ in length and $20-40 \mathrm{~nm}$ in diameter.

In 2D structures of $\mathrm{ZnO}$ NPs/MPs, $\mathrm{ZnO}$ nanodisks were prepared using co-precipitation by reacting with $1 \mathrm{mM}$ zinc acetate dihydrate and $2 \mathrm{M}$ sodium hydroxide in water at room temperature [57]. The nanodisks, theoretically calculated at $41 \mathrm{~nm}$, showed a minimum toxicity (LD50 for brine shrimps, $>200 \mu \mathrm{g} / \mathrm{mL}$ ) compared to those synthesized in other solvents, including acetone (size, $29.1 \mathrm{~nm}$; LD50, $83.2 \mu \mathrm{g} / \mathrm{mL}$ ), ethyl acetate (size, $40.1 \mathrm{~nm}$; LD50, $140.3 \mu \mathrm{g} / \mathrm{mL}$ ), ethanol (size, $33.7 \mathrm{~nm}$; LD50, $90 \mu \mathrm{g} / \mathrm{mL}$ ), and methanol (size, $32.8 \mathrm{~nm}$; LD50, $49.4 \mu \mathrm{g} / \mathrm{mL}$ ), with the exception of chloroform (size, $38.5 \mathrm{~nm}$; LD50, >200 $\mu \mathrm{g} / \mathrm{mL}$ ). Platelet-shape ZnO NPs of different sizes $(14.7 \mathrm{~nm}$ and $17.5 \mathrm{~nm}$ ) were also reported by Pasquet et al. [58], in which size distribution was less than $100 \mathrm{~nm}$ despite the particle size increasing to 5.0-6.4 $\mu \mathrm{m}$ in a hydrodynamic environment. The particles had mesopores of $11.6-17.3 \mathrm{~nm}$ and a specific surface area of $39.0-46.9 \mathrm{~m}^{2} / \mathrm{g}$.

In $3 \mathrm{D}$ structured $\mathrm{ZnO}$ NPs / MPs such as antibiotic agents, flower-like ZnO MPs were synthesized using electrochemical-thermal method with poly-diallyl-(dimethylammonium) chloride (PDDA) and benzyl-dimethylammonium chloride (BAC) as a stabilizer, which were 200-500 nm or 1-2 $\mu \mathrm{m}$ long [45]. Flower-shaped ZnO NPs were also synthesized using the sol-gel method reacting with $5 \%$ zinc acetate dihydrate and $0.2 w / v \%$ cetyltrimethyl ammonium bromide (CTAB) at $\mathrm{pH} 11.7-11.9$, and $25-75{ }^{\circ} \mathrm{C}$ of near-room temperatures [59]. They showed enhanced antibacterial and antifungal performance via larger zones of growth inhibition when compared to $\mathrm{ZnO}$ powders and conventional products. Flower-like $\mathrm{ZnO}$ NPs were further reported by Quek et al. [60], which were sized at $700 \mathrm{~nm}-2.2 \mu \mathrm{m}$ in diameter for visible light-responsive photocatalytic antimicrobial action. Talebian et al. [61] described higher antibacterial activity of flower-shaped ZnO NPs compared to those of rod- and sphere-shaped ZnO NPs. The flower-shaped ZnO NPs were synthesized using the solvothermal technique reacting with zinc acetate dihydrate in water $(5.6 \mathrm{~g} / 50 \mathrm{~mL})$ and $0.5 \mathrm{M}$ sodium hydroxide. They resulted in a smaller particle $(45 \mathrm{~nm})$ with larger surface area $\left(28.8 \mathrm{~m}^{2} / \mathrm{g}\right)$ than ZnO NPs synthesized in 1-hexanol (rod shape; $76 \mathrm{~nm} ; 15.5 \mathrm{~m}^{2} / \mathrm{g}$ surface area) and ethylene glycol (sphere shape; $65 \mathrm{~nm} ; 19.2 \mathrm{~m}^{2} / \mathrm{g}$ surface area), predicting enhanced antimicrobial performance. At this point, it is believed that the solvent in the solvothermal technique is a critical parameter in the synthesis of $\mathrm{ZnO}$ NPs, which results in differentiated morphology. Star-shaped ZnO NPs were also synthesized at $31 \mathrm{~nm}$ using liquid precipitation for preparing microorganism-protective defense clothing on cotton or polyester fabrics due to their biocompatibility [62]. Using co-precipitation, flake-shaped $\mathrm{ZnO}$ NPs were prepared at $32 \mathrm{~nm}$ size for enhanced antimicrobial performance [63].

Therefore, irrespective of $\mathrm{ZnO} \mathrm{NP} / \mathrm{MP}$ variety, the physicochemical characteristics of ZnO NPs / MPs affect their antimicrobial activity against pathogenic microorganisms [14,64], and synthesis techniques can be controlled to improve the properties of ZnO NPs/MPs for enhanced antimicrobial performance $[13,65]$.

\section{Antimicrobial ctivity against Pathogenic Microorganisms}

\subsection{Antimicrobial Mechanisms of $\mathrm{ZnO}$ Materials}

Mechanisms of antimicrobial actions of $\mathrm{ZnO}$ materials have been explained in association with particular interaction based on their unique physicochemical properties of (a) $\mathrm{Zn}^{2+}$ ion release, (b) adsorption, and (c) ROS generation [14,66], and the intracellular responses in microorganisms of $(\mathrm{d})$ energy metabolism inhibition; (e) lipid peroxidation, 
and cell membrane damage; and (f) DNA replication disruption, and DNA break [67,68] (Figure 1). The $\mathrm{Zn}^{2+}$ ions that are released from $\mathrm{ZnO}$ NPs/MPs induce an antimicrobial response in microorganisms due to interference in metabolic processes and disturbance in enzymatic systems $[69,70]$. ZnO NPs/MPs also have functions of particle adsorption to the biomembrane via a charge-charge interaction, and ROS generation as photocatalysts under UV and visible light irradiation [3,12,71,72]. Positively charged surfaces of ZnO NPs/MPs interact with the negatively charged cell wall or biomembrane of microorganisms [73]. They are internalized into the microorganisms after adsorption resulting in loss of cell integrity based on cell wall or membrane rupture, and further mediate oxidative stress owing to lipid peroxidation leading to deoxyribonucleic acid (DNA) damage. Based on the fundamental mechanisms of action, ZnO NPs/MPs have a differential susceptibility against pathogenic microorganisms, affected by their physicochemical characteristics including morphology, particle size, and porosity [3,17,18,73].

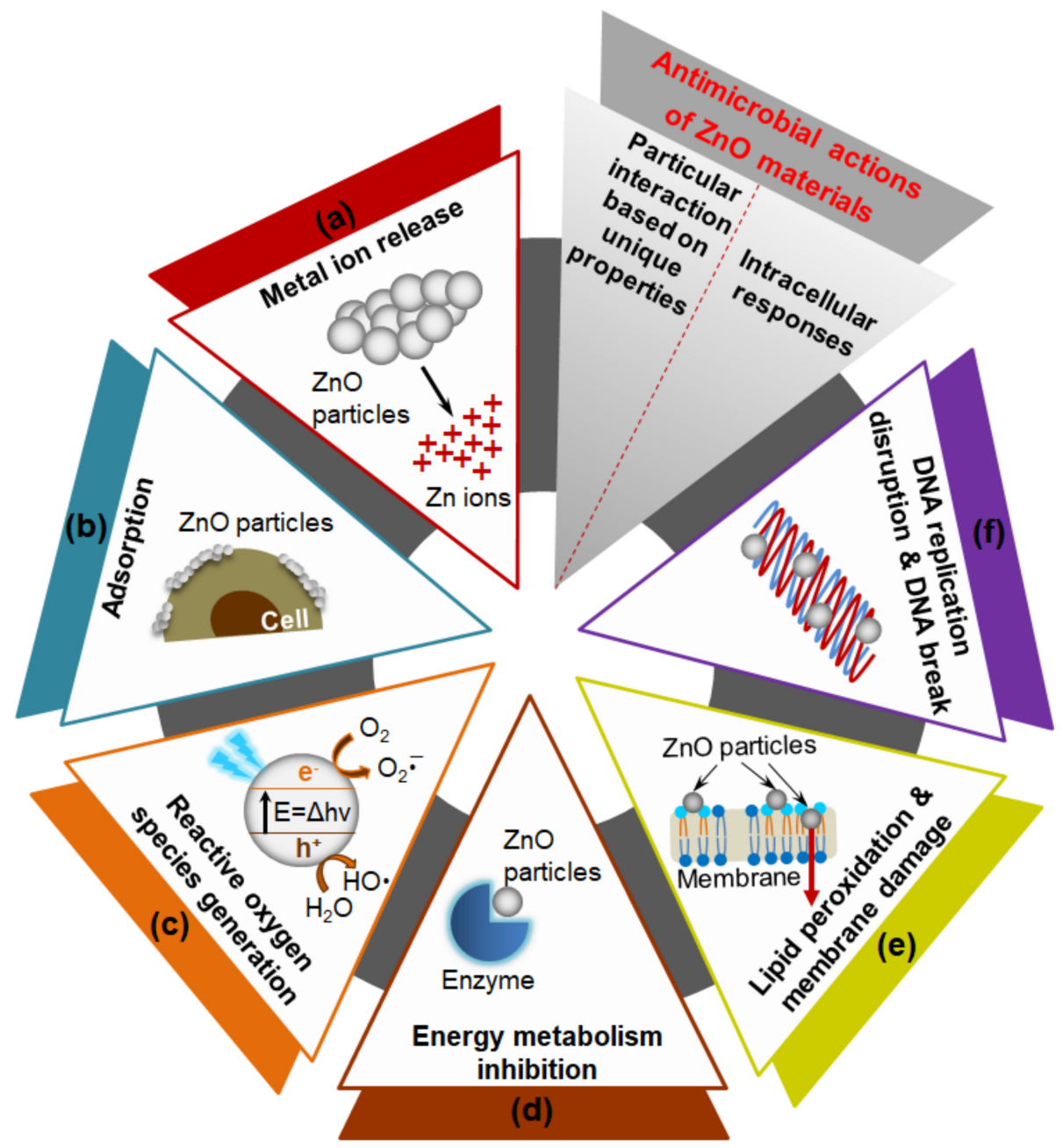

Figure 1. Mechanisms of zinc oxide $(\mathrm{ZnO})$ materials used in antimicrobial applications: Particular interactions of (a) metal ion release, (b) adsorption, and (c) reactive oxygen species generation based on their physicochemical properties; and following intracellular responses of (d) energy metabolism inhibition, (e) lipid peroxidation and membrane damage, and (f) DNA replication disruption and DNA break.

In the photocatalytic activation of $\mathrm{ZnO}$ NPs / MPs for ROS generation linked to oxidative stress, electrons $\left(\mathrm{e}^{-}\right)$are transmitted from the valence band to the conduction band by the photoexcitation over band gap energy $(E=\Delta h v)$ leaving positive holes $\left(h^{+}\right)[14,65]$. Holes in the valence band produce hydroxyl radicals $(\mathrm{OH} \cdot)$, whereas electrons in the 
conduction band generate superoxide radical anions $\left(\mathrm{O}_{2} \cdot{ }^{-}\right)$in an aqueous environment. Reacting with electrons and hydrogens, hydroxyl peroxide radicals $\left(\mathrm{HO}_{2} \cdot\right)$ and finally hydrogen peroxide $\left(\mathrm{H}_{2} \mathrm{O}_{2}\right)$ are formed. In addition, surface defects of $\mathrm{ZnO}$ NPs can enhance ROS production even in the dark for enhanced antimicrobial performance [74].

In 3D structures of $\mathrm{ZnO} N \mathrm{Ns} / \mathrm{MPs}$ followed by aggregate formation or nanostructure generation, multiple scattering can be one of several antimicrobial mechanisms to improve photocatalytic performance based on enhanced mass transfer and exchange [18,75]. The bimodal porous self-assembled network of ZnO NPs, with mesopores and macropores was reported to enhance the photocatalytic antimicrobial action caused by multiple scattering under dual UV irradiation [18]. Hierarchically porous self-forming structured aggregates of polydispersed ZnO NPs showed a submicron size of 100-500 nm in diameter, which enhanced the multiple scattering phenomenon [75]. Thus, the hierarchically porous structure of $\mathrm{ZnO}$ NPs/MPs mediating multiple scattering can counteract the undesirable photocatalytic performance, which prevents large particles from retaining a small surface area.

Compared to other metal or metal oxide NPs/MPs, ZnO NPs/MPs have multiple functional mechanisms of antimicrobial performance [4]. In antibiotic metals such as silver $(\mathrm{Ag})$ and gold $(\mathrm{Au})$, NPs have the primary functions of metal ion release and membrane adsorption, respectively. In general, titanium dioxide, cupric oxide $(\mathrm{CuO})$, and magnesium oxide (MgO) NPs display ROS generation, NP internalization, and membrane damage, respectively. Regardless of the susceptibility of pathogenic microorganisms to antimicrobial activity, ZnO NPs/MPs can combat microbial regrowth to overcome multi-drug resistance of conventional antibiotics based on targeting antibiotic-resistant pathways in a non-specific manner, irrespective of NP penetration into microorganisms [7,30,76].

Meanwhile, $\mathrm{ZnO}$ NP/MP combinations with other materials displayed comparable antimicrobial activity against pathogenic microorganisms $[77,78]$. In these studies, the materials were mixed or conjugated with $\mathrm{ZnO}$ NPs/MPs, with a view to improving their usability and sustainability in biomedical applications, compared to ZnO NPs/MPs alone. Combinatorial materials used with ZnO NPs/MPs also showed antimicrobial activity using different mechanisms to overcome multi-drug resistance. These included antibiotic or antiinflammatory drugs $[20,47,79]$, other metal oxide NPs/MPs or metal doping [80,81], polymers (e.g., chitosan and alginate) [28,82,83], carbon-based materials (e.g., graphene [84,85], graphene oxide (GO) [86,87], and reduced graphene oxide (rGO) [88]), and quantum dots (QDs) $[89,90]$. They enhanced ROS generation or mediated the other antimicrobial pathways of ZnO NPs/MPs in microorganisms to create an additive or synergistic microbial growth inhibition benefit. However, the reduced or antagonistic disadvantages of antimicrobial performance sometimes occurred due to microbial susceptibility $[20,81,91]$.

\subsection{ZnO Materials and Combinations Based on Antimicrobial Functions}

$\mathrm{ZnO}$ NPs/MPs have been studied to enhance their antimicrobial activity against pathogenic microorganisms [33,92]. In addition to improving their physicochemical characteristics, antimicrobial activities of combinations of $\mathrm{ZnO}$ NPs/MPs with other biomaterials have been explored for enhanced antimicrobial performance [93,94]. Table 2 presents the antimicrobial activity of (i) ZnO NPs/MPs, (ii) ZnO NPs/MPs with antibiotic or antiinflammatory drugs, (iii) ZnO NPs/MPs with other metal oxide NPs/MPs or metal doping, (iv) ZnO NPs /MPs with other polymeric biomaterials or films, and (v) ZnO QDs.

\subsubsection{ZnO Materials}

The antimicrobial activity of various-sized or -shaped ZnO NPs/MPs has been investigated against pathogenic bacteria as well as viruses $[3,69,95]$. ZnO NPs/MPs show various forms as spheres, cubes, pyramids, rods, tubes, donuts, platelets, mixtures, and 3D architectures of clusters or networks, ranging from $3.4 \mathrm{~nm}$ to $30 \mu \mathrm{m}$ in size. Size-dependent antimicrobial activity of spherical $\mathrm{ZnO}$ NPs of $12-307 \mathrm{~nm}$ was described against S. aureus, Proteus vulgaris, Salmonella typhimurium, Shigella flexneri, and Bacillus cereus [16]. Smaller NPs (12-30 nm) showed a superior antimicrobial growth inhibition $(\sim 94.05 \%)$ than larger 
NPs at the same concentration $(6 \mathrm{mM})$. In addition, three types of ZnO NPs shaped like hexagons, spheres, and cubes or rods showed antimicrobial activity against $E$. coli, S. aureus, and B. subtilis [17]. The minimum inhibitory concentration (MIC) levels of ZnO NPs at $\sim 63 \mathrm{~nm}, \sim 65 \mathrm{~nm}$ and $60-180 \mathrm{~nm}$, and $40-45 \mathrm{~nm}$ were determined as $1562 \mu \mathrm{g} / \mathrm{mL}$ against $E$. coil, 391-781 $\mu \mathrm{g} / \mathrm{mL}$ against $S$. aureus, and $195-391 \mu \mathrm{g} / \mathrm{mL}$ against $B$. subtilis, respectively. $\mathrm{ZnO}$ nanopyramids at $\sim 15.4 \mathrm{~nm}$ in a segment showed an MIC of $333 \mu \mathrm{g} / \mathrm{mL}$ against MRSA [96]. DeLucas-Gil et al. [19] illustrated that nanostructured $\mathrm{ZnO}$ of spherical NP clusters at $590 \mathrm{~nm}$ in diameter, had superior antimicrobial activity against $E$. coli and $S$. aureus at $>3.5 \log$ (control/sample) value than the ZnO NPs at $63 \mathrm{~nm}$ in diameter.

$\mathrm{ZnO}$ nanorods, at $<100 \mathrm{~nm}$ or ranging from $500 \mathrm{~nm}$ to $1 \mu \mathrm{m}$, also showed an antimicrobial activity against pathogenic microorganisms [97,98]. Reddy et al. [99] reported antimicrobial activity of $\mathrm{ZnO}$ nanorods at $88.7 \mathrm{~nm}$ against $K$. pneumoniae, for which the MIC was $40 \mu \mathrm{g} / \mathrm{mL}$. These NPs were synthesized by the precipitation method using 2mercaptoethanol as a capping agent. Tahizdeh et al. [100] reported that $\mathrm{ZnO}$ nanorods at an MIC of $250 \mu \mathrm{g} / \mathrm{mL}$ had antimicrobial activity against E. coli, P. aeruginosa, S. aureus, and Enterococcus faecalis, excluding E. faecalis which was resistant to $\mathrm{ZnO}$ nanorods. These nanorods were small crystals $3.4 \mathrm{~nm}$ in size and the NPs were $150 \mathrm{~nm}$ in length and $21 \mathrm{~nm}$ in width (aspect ratio, 7.14). Nanometric $\mathrm{ZnO}$ were synthesized using ethylenediamine and citric acid monohydrate as capping agents; the antimicrobial activity of the resulting nanorod-shaped particles (500 $\mathrm{nm}$ to $1.0 \mu \mathrm{m}$ ) was affected by the synthesis technique [101]. $\mathrm{ZnO}$ nanorods synthesized with ethylenediamine showed antimicrobial activity against $E$. coli but not against Micrococcus luteus. Conversely, $\mathrm{ZnO}$ nanorods synthesized using citric acid monohydrate showed growth inhibition for M. luteus but not for E. coli.

Elkady et al. [54] reported antimicrobial activity against E. coli, S. aureus, P. aeruginosa, and B. subtilis using as-synthesized $\mathrm{ZnO}$ nanopowders of hexagonal hollow tube shapes $\sim 500 \mathrm{~nm}$ in length with $17.8 \mathrm{~m}^{2} / \mathrm{g}$ surface area and $278.6 \mathrm{~nm}$ average pore size. Their MIC values were found to be $0.0585 \mathrm{mg} / \mathrm{mL}$ for $E$. coli (zone of inhibition, $13 \mathrm{~mm}$ ), $0.234 \mathrm{mg} / \mathrm{mL}$ for S. aureus (zone of inhibition, $14 \mathrm{~mm}$ ), $0.234 \mathrm{mg} / \mathrm{mL}$ for $P$. aeruginosa (zone of inhibition, $18 \mathrm{~mm}$ ), and $0.938 \mathrm{mg} / \mathrm{mL}$ for B. subtilis (zone of inhibition, $15 \mathrm{~mm}$ ) using disk diffusion. Hollow nanotubes of $\mathrm{ZnOs}$ were also reported by López de Dicastillo et al. [55]. They were coated on acrylic polymer/extruded $32 \mu \mathrm{m}$-polyethylene (PE) substrate at $1 \%(\mathrm{wt}$ ) and were $\sim 5 \mu \mathrm{m}$ in length, $59.5 \mathrm{~nm}$ in thickness, and $178.2 \mathrm{~nm}$ in internal diameter. The hollow nanotubes reduced microbial growth against E. coli by $4.67 \mathrm{log}\left(\mathrm{cells} / \mathrm{cm}^{2}\right)$ and $S$. aureus by $2.46 \log \left(\mathrm{cells} / \mathrm{cm}^{2}\right)$.

Pasquet et al. [58] reported antimicrobial activity by three-different $\mathrm{ZnO}$ NPs ( $\mathrm{ZnO}-1$, $\mathrm{ZnO}-2$, and $\mathrm{ZnO}-3$ ) based on differences in the physicochemical characteristics including NP size and morphology of platelets and rods against E. coli, S. aureus, P. aeruginosa, Candida albicans, and Aspergillus brasiliensis. Platelet-like ZnO NPs (ZnO-1 and ZnO-2) and rod-like ZnO NPs (ZnO-3) formed crystal sizes of $14.7 \mathrm{~nm}, 17.5 \mathrm{~nm}$, and $76.2 \mathrm{~nm}$, with corresponding surface areas and mesopore sizes of $39.0 \mathrm{~m}^{2} / \mathrm{g}$ and $17.3 \mathrm{~nm}, 46.9 \mathrm{~m}^{2} / \mathrm{g}$ and $11.6 \mathrm{~nm}$, and $8.25 \mathrm{~m}^{2} / \mathrm{g}$ and $10.6 \mathrm{~nm}$, respectively. The MIC levels of $\mathrm{ZnO}-1, \mathrm{ZnO}-2$, and ZnO-3 were $0.12 \%, 0.18 \%$, and $2.30 \%(w / w)$ for $E$. coli; $0.25 \%, 0.30 \%$, and $3.40 \%(w / w)$ for $S$. aureus; $1.28 \%, 4.68 \%$, and $5.70 \%(w / w)$ for $P$. aeruginosa; and $>8 \%,>8 \%$, and $>8 \%(w / w)$ for C. albicans, respectively. No growth inhibition was detected against $A$. brasiliensis. Lower MIC levels against microorganisms were detected when using smaller ZnO NPs (ZnO-1< $\mathrm{ZnO}-2<\mathrm{ZnO}-3)$.

Three-dimensional structured ZnO NPs also displayed antimicrobial activity against pathogenic microorganisms [14,18]. Jin et al. [18] presented the antimicrobial activity of self-assembled networks of spherical $\mathrm{ZnO}$ NPs at $\sim 3 \mu \mathrm{m}$ against $E$. coli under dual UV irradiation for $30 \mathrm{~s}$. No colonies were detected at $0.05 \mathrm{mg} / \mathrm{mL}$ of self-assembled $\mathrm{ZnO}$ networks, whereas colonies at 2.8-3.0 $\log (\mathrm{CFU} / \mathrm{mL})$ were grown after no particle treatment.

$\mathrm{ZnO}$ NP mixtures at $25 \mathrm{~nm}(1600-3200 \mu \mathrm{g} / \mathrm{mL})$ particularly had an antimicrobial activity against $P$. aeruginosa isolates from patients which were resistant to amikacin $(30 \mu \mathrm{g})$, cefepime $(30 \mu \mathrm{g})$, sparfloxacin $(5 \mu \mathrm{g})$, piperacillin $(100 \mu \mathrm{g})$, levofloxacin $(5 \mu \mathrm{g})$, piperacilin- 
tazobactum $(100 / 10 \mu \mathrm{g})$, imipenem $(10 \mu \mathrm{g})$, tobramycin $(10 \mu \mathrm{g})$, nitrofurantoin $(300 \mu \mathrm{g})$, and ceftazidime $(30 \mu \mathrm{g})$ [102].

In $\mathrm{ZnO}$ MPs, tetrapod-type $\mathrm{ZnO}$ NPs which were $\sim 30 \mu \mathrm{m}$ in size had antimicrobial activity against Herpes simplex virus type-2 (HSV-2) as ZnO tetrapod NPs and HSV-2 cocktail for live virus vaccine $[95,103]$. ZnO microdonuts were reported by Jeyabharathi et al. [104]. They were nano-to microscale sized donuts at 1-2 $\mu \mathrm{m}$, and showed growth inhibition against Enterobacter aerogenes and Staphylococcus epidermidis at $0.5-5 \mathrm{mM}$.

\subsubsection{ZnO Materials with Drugs}

Combinations of ZnO NPs/MPs with drugs including antibiotic agents and antiinflammatory agents have been studied to enhance antimicrobial activity against pathogenic microorganisms [20,21,79,105,106]. Pharmaceutical formulations of ZnO NPs/MPs with antibiotic drugs, anti-inflammatory drugs, or natural products were conventionally used as endodontic dressing (clindamycin and triamcinolone) [107]; dental cements for temporary implants (eugenol) [108,109]; and medical devices or health care products for skin irritation, minor burns, or wounds (aloe vera) [110,111]. In recent approaches to $\mathrm{ZnO} \mathrm{NP} / \mathrm{MP}$ combinations with drugs, various antibiotic drugs were used including azithromycin, gentamicin, oxacillin, cefotaxime, cefuroxime, fosfomycin, chloramphenicol, oxytetracycline [20], cephalexin [21], ciprofloxacin, imipenem [79], ceftriaxone, ceftazidime, gentamicin [105], and ampicillin/sulbactam [106].

The antimicrobial activity of flake ZnO NPs ( 200 nm in length) with azithromycin, gentamicin, oxacillin, cefotaxime, cefuroxime, fosfomycin, chloramphenicol, and oxytetracycline, was demonstrated against E. coli, S. aureus, Salmonella enterica subsp. Bukuru, and C. albicans [20]. The combination effects of ZnO NPs with these antibiotics were categorized by synergistic and antagonistic responses compared to ZnO NPs alone at MIC levels of $1.25 \mathrm{mg}$ against E. coli, S. aureus, and S. enterica subsp. Bukuru, excluding C. albicans, which had no growth inhibition. Synergistic antimicrobial responses were presented in $\mathrm{ZnO}$ NPs (10 mg) with specific antibiotics against microorganisms: azithromycin, oxacillin, cefotaxime, cefuroxime, fosfomycin, and oxytetracycline against E. coli; azithromycin, cefotaxime, cefuroxime, fosfomycin, chloramphenicol, and oxytetracycline against S. aureus; and oxacillin, cefuroxime, and fosfomycin against Sallmonella species. However, $\mathrm{ZnO}$ NPs (10 mg) with azithromycin, gentamicin, cefotaxime, neomycin, ampicillin/sulbactam, chloramphenicol, and oxytetracycline had antagonistic antimicrobial responses against Sallmonella species. Meanwhile, using $\mathrm{ZnO}$ nanohybrids of squeezed $\mathrm{ZnO}$ crystals with cephalexin, an MIC level was reported at $1 \mathrm{mg} / \mathrm{mL}$ even against Aeromonas species [21].

Farzana et al. [79] reported MIC levels of ZnO NPs with ciprofloxacin against E. coli and $K$. pneumonia at $0.2-1 \mathrm{mg} / \mathrm{mL}$ compared to 0.08 and $0.05 \mathrm{mg} / \mathrm{mL}$ for $\mathrm{ZnO}$ NPs alone, respectively. However, $\mathrm{ZnO}$ NPs with imipenem had no growth inhibition with decreasing antimicrobial effect except for one K. pneumonia strain.

Spherical ZnO NPs (15.3-37 nm) with ceftriaxone, ceftazidime, and gentamicin showed growth inhibition against E. coli, K. pneumonia, S. aureus, E. faecalis, P. aeruginosa, and Shigella flexneri [105]. Compared to ZnO NPs (MIC, 4-16 $\mu \mathrm{g} / \mathrm{mL}$; except P. aeruginosa, $>64 \mu \mathrm{g} / \mathrm{mL}$ ) and antibiotics (MIC, 9-13 $\mu \mathrm{g} / \mathrm{mL}$ ), after $24 \mathrm{~h}$ incubation, ZnO NPs with ceftriaxone, ceftazidime, and gentamicin showed 89-90\%, 96-99\%, and 95-98\% growth inhibition levels against E. coli, K. pneumonia, and S. aureus, respectively. Growth inhibition levels of $95 \%, 3.8 \%$, and $96 \%$ were also observed against E. faecalis, P. aeruginosa, and $S$. flexneri, respectively, for ZnO NPs with ceftriaxone, ceftazidime, and gentamicin.

Sharma et al. [106] described antimicrobial activity of ZnO NPs (25 nm) with ampicillin/sulbactam against E. coli, K. pneumoniae, P. aeruginosa, S. typhi, and S. aureus. MIC levels of ampicillin/sulbactam were $50 \mu \mathrm{g} / \mathrm{mL}$ against E. coli, S. typhi, and S. aureus; and $100 \mu \mathrm{g} / \mathrm{mL}$ against K. pneumoniae and P. aeruginosa, whereas MIC levels of $\mathrm{ZnO}$ NPs alone were 25-200 $\mu \mathrm{g}$. Although the MIC level of ZnO NPs was $25 \mu \mathrm{g}$ and that of ampicillin/sulbactam was $100 \mu \mathrm{g} / \mathrm{mL}$ against K. pneumoniae, the MIC level of the ZnO NP- 
ampicillin/sulbactam conjugated form against K. pneumoniae was $6.25 \mu \mathrm{g} / \mathrm{mL}$, suggesting antimicrobial activity enhancement.

\subsubsection{ZnO Materials with Other Metal Oxide NPs/MPs or Metal Doping}

$\mathrm{ZnO}$ NPs/MPs have also been studied as combinatorial composites or surface coating agents for enhanced antimicrobial activity against pathogenic microorganisms. Titanium dioxide $\left(\mathrm{TiO}_{2}\right) \mathrm{NPs} / \mathrm{MPs}, 4 \mathrm{~A}$ zeolite $\left(\mathrm{Na}_{12}\left[\left(\mathrm{AlO}_{2}\right)_{12}\left(\mathrm{SiO}_{2}\right)_{12}\right] \cdot 27 \mathrm{H}_{2} \mathrm{O}\right)$, and silica $\left(\mathrm{SiO}_{2}\right)$ were included in combinations of ZnO NPs/MPs [112-114]. In addition, doping of antibiotic metals (e.g., $\mathrm{Ag}$ and $\mathrm{Cu}$ ) to $\mathrm{ZnO} \mathrm{NPs} / \mathrm{MPs}$ has been reported for enhanced antimicrobial performance [81,105,115-117].

Azizi-Lalabadi et al. [80] described growth inhibition of $\mathrm{ZnO} N P s$ with $\mathrm{TiO}_{2} \mathrm{NPs}_{\mathrm{N}}$ in $4 \mathrm{~A}$ zeolite against $E$. coli $\mathrm{O} 157: \mathrm{H7}$, S. aureus, Pseudomonas fluorescens, and Listeria monocytogenes at MIC levels of 1, 2, 1, and $2 \mathrm{mg} / \mathrm{mL}$, respectively. The $\mathrm{ZnO} \mathrm{NPs} / \mathrm{TiO}_{2} \mathrm{NPs} / 4 \mathrm{~A}$ zeolites in combinations were cube-shaped at 400-600 nm, in which spherical ZnO NPs with $\sim 50 \mathrm{~nm}$ were included. In addition, $\mathrm{Ag}-\mathrm{ZnO} \cdot \mathrm{mSiO}_{2}$ composites reported by Bednář et al. [81], were lamellar porous nanostructures with $\mathrm{Ag}$ spots having $250 \mathrm{~m}^{2} / \mathrm{g}$ of specific surface area, and had antimicrobial activity against E. coli, P. aeruginosa, Streptococcus salivarius, S. aureus, and C. albicans at MIC levels of $2.9 \mathrm{mg} / \mathrm{cm}^{3}, 3.9,5.9,5.9$, and $23.5 \mathrm{mg} / \mathrm{cm}^{3}$, respectively. The Ag- $\mathrm{ZnO} \cdot \mathrm{mSiO}_{2}$ composites also showed synergistic antimicrobial activity based on $\mathrm{Ag}$ and $\mathrm{ZnO}$ interaction, compared to $\mathrm{ZnO} \cdot \mathrm{mSiO}_{2}$ alone. However, $\mathrm{ZnO}-\mathrm{SiO}_{2}$ composites displayed by Donnadio et al. [115] had antimicrobial activity against $S$. aureus and C. albicans at MIC levels of $2 \mathrm{mg} / \mathrm{mL}$ (except for ZnO/S-S-20, C-A-10, or C-A-20, >2) as $0.228-0.632 \mathrm{mg} / \mathrm{mL}$ of $\mathrm{ZnO}$ NPs and 1 or $2 \mathrm{mg} / \mathrm{mL}$ (except for ZnO/S-A-10 or S-S-10 >2) as $0.187-0.632 \mathrm{mg} / \mathrm{mL}$ of $\mathrm{ZnO}$ NPs, respectively. These $\mathrm{ZnO}^{-S_{\mathrm{SiO}}}{ }_{2}$ composites were structured $\mathrm{ZnO}$ nanorods of $30-50 \mathrm{~nm}$ on the silica surface with specific surface areas of $20-70 \mathrm{~m}^{2} / \mathrm{g}$.

In $3 \mathrm{D}$ porous architectures, CuZnO NPs on mesoporous silica SBA-3 had highly ordered mesoporous structures of near-spherical NPs $\sim 2 \mu \mathrm{m}$ in size, $3.6274 \mathrm{~nm}$ in pore size, and $829 \mathrm{~m}^{2} / \mathrm{g}$ in specific surface area with a relatively rough surface [117]. They showed growth inhibition against $E$. coli and S. aureus at MIC levels of $25 \mathrm{mg} / \mathrm{mL}(0.558 \mathrm{mg} / \mathrm{mL}$ as CuZnO NPs) and $6.25 \mathrm{mg} / \mathrm{mL}(0.139 \mathrm{mg} / \mathrm{mL}$ as CuZnO NPs), respectively.

Moreover, $\mathrm{ZnO}$ MPs with $\mathrm{TiO}_{2} \mathrm{MPs}$ showed antimicrobial activity against E. coli, Streptococcus pyogenes, and K. pneumoniae under UV and visible light irradiation [118]. Using $\mathrm{ZnO}$ MPs at $0.25 \%$ and $\mathrm{TiO}_{2} \mathrm{MPs}$ at $1 \%$, growth inhibition levels were $76.8 \%$ against E. coli, $70.2 \%$ against $S$. pyrogenes, and $80.8 \%$ against $K$. pneumoniae. ZnO MPs synergistically enhanced antimicrobial activity against pathogenic microorganisms compared to UV and visible light-irradiated $\mathrm{TiO}_{2}$ MPs alone. The $\mathrm{ZnO}$ MPs in combinations had near-spherical shape, with sizes of 3.17-10.3 $\mu \mathrm{m}$ compared to $2.15-37.1 \mu \mathrm{m}$ of the $\mathrm{TiO}_{2} \mathrm{MPs}$.

\subsection{4. $\mathrm{ZnO}$ Materials with Other Biomaterials}

Antimicrobial polymeric biomaterials or films are used as additive composites in $\mathrm{ZnO} \mathrm{NP} / \mathrm{MP}$ combinations for enhanced antimicrobial activity against pathogenic microorganisms. Recently studied antibiotic biomaterials or films $[26,28]$ in ZnO NPs/MPs combinations included chitosan [28,82,84], silk sericin [84], gelatin [91], gallic acid [28], hydroxyapatite [83,119], alginate [83], polyethyleneglycol (PEG) [120], biopolymer K [27], carrageenan [27], bacterial cellulose [121,122], propolis extract [121], curcumin [84,123,124], graphene [84,85], graphene oxide (GO) $[86,87,125]$, reduced graphene oxide (rGO), and cotton [88,126-129]. In general, they enhanced the antimicrobial activity of ZnO NPs/MPs and overcame formulation challenges of $\mathrm{ZnO}$ NPs/MPs in manufacturing beads or films and covering surfaces for coating.

Among natural products, chitosan has been extensively studied as a pharmaceutical excipient for drug delivery carriers in biomedical applications owing to their biocompatibility and physicochemical characteristics [113,114]. It is beneficial to have inherent therapeutic functions including antimicrobial activity and anti-inflammatory activity for accelerated wound healing, hemostasis, and reduced fat absorption to decrease plasma and liver lipids 
and increase fecal excretion [114,130]. Regarding the biomedical functions of chitosan, the antimicrobial mechanisms are explained by cell binding via charge-charge interaction owing to the polycationic nature of chitosan, leading to disruption of the membrane and inhibition of nucleic acid processes, thereby causing cell death. As a chelating agent, chitosan also interacts with trace metal elements, which are toxic to cells, inducing microbial growth inhibition. It is applied for wound dressing/healing, cotton fabric, daily food packaging, and paper packaging as an antimicrobial agent, mostly in films [113,131-134]. Therefore, chitosan can be extended to the combinations with ZnO NPs/MPs [135].

Chitosan-ZnO NP-loaded gallic acid (C-ZnO@gal) films showed antimicrobial activity against E. coli and B. subtilis [28]. ZnO@gal NPs were near-rod-shape at $\sim 19.2 \mathrm{~nm}$, and C-ZnO@gal films included homogeneously distributed ZnO@gal NPs on chitosan matrixes (2 g chitosan/70 mg ZnO@gal) at a thickness of $0.10 \mathrm{~mm}$. Using C-ZnO@gal films at $0.5 \mathrm{mg} / \mathrm{mL}$, growth inhibition zone levels were reported as $28 \mathrm{~mm}$ against $E$. coli and $25 \mathrm{~mm}$ against $B$. subtilis. Al-Nabulsi et al. [82] described the antimicrobial activity of $\mathrm{ZnO}$ NP-containing chitosan against E. coli O157:H7, which was used as a biocompatible coating agent for smart storage. The ZnO NPs had a near-spherical shape at $\sim 65 \mathrm{~nm}$ and were uniformly distributed in chitosan matrixes. The growth reduction levels against $E$. coli O157:H7 at $4{ }^{\circ} \mathrm{C}$ were $2.5 \log (\mathrm{CFU} / \mathrm{g})$ for chitosan $(2.5 \%, w / v)$ and $2.8 \log (\mathrm{CFU} / \mathrm{g})$ for $\mathrm{ZnO}$ $\mathrm{NP}(1 \%, w / v)$-containing chitosan $(2.5 \%, w / v)$. Although combinations of ZnO NPs in a chitosan matrix did not show a significant improvement of antimicrobial activity against $E$. coli O157:H7 ( $p>0.05)$ compared to ZnO NPs or chitosan alone, the ZnO NP combination in the chitosan matrix presented better antimicrobial results.

Kumar et al. [91] reported growth inhibition levels of chitosan/gelatin hybrid nanocomposite films containing $\mathrm{ZnO}$ NPs against $E$. coli and S. aureus along with their improved structural integrity. In these films, ZnO NPs had various shapes such as polyhedrons, quasi-spheres, or rods of 20-40 nm, 500-1000 nm, and 200-400 nm, respectively, which were evenly distributed on smooth, compact, and heterogeneous surfaces with 86-92 $\mu \mathrm{m}$ in thickness. Depending on the ZnO NP contents in the films, their antimicrobial activity against $E$. coli presented a $10.5 \mathrm{~mm}$ zone of growth inhibition for $\mathrm{ZnO} \mathrm{NPs}$ at $1 \%$ and $2 \%$ in the films and a $10.7 \mathrm{~mm}$ zone of growth inhibition for $\mathrm{ZnO}$ NPs at $4 \%$ in the films. The films showed comparable growth inhibition results based on inherent antimicrobial activity of chitosan. Unlike the effects against $E$. coli, no prominent results were obtained for $S$. aureus.

Three-dimensional porous $\mathrm{ZnO} N \mathrm{~N}$ scaffolds with chitosan/silk/sericin for wound dressing/healing were described as antimicrobial agents against E. coli and S. aureus [136]. Their porous microstructures $\left(1.5 \times 1.5 \mathrm{~cm}^{2}\right)$ comprising $2 \%(w / v)$ chitosan, and $100 \mu \mathrm{L}$ or $250 \mu \mathrm{L}$ of $\mathrm{ZnO}$ NPs (40\% dispersion, wt), showed $\sim 86 \%$ porosity with $4-200 \mu \mathrm{m}$ in pore size. Based on the zone of growth inhibition via the disk diffusion method for evaluation, these particles displayed $2-4.5 \mathrm{~mm}$ growth inhibition against $E$. coli and $2.5-5.5 \mathrm{~mm}$ growth inhibition against $S$. aureus.

In particular, Javed et al. [137] reported a biodental materials for orthodontics, composed of star-shaped, chitosan-based ZnO NPs (20-25 nm), which showed enhanced antimicrobial activity against K. pneumoniae (13 $\mathrm{mm}$ zone of inhibition, the highest); E. coli, P. aeruginosa; and B. subtillis, S. aureus, and MRSA (6 mm zone of inhibition, the lowest), compared to those composed of ZnO NPs or chitosan alone. In the synthesis of chitosanbased ZnO NPs via co-precipitation, zinc acetate dihydrate $(0.06 \mathrm{M})$ and chitosan were used as a precursor and a capping agent, respectively. Conventionally used adhesive was coated using chitosan-based ZnO NPs at 2-10\%. The pure ZnO NPs had a spherical shape with a diameter of $25-30 \mathrm{~nm}$.

Meanwhile, hydroxyapatite-biphasic ZnO NP/MP-embedded alginate (HA-ZnOAlg) beads showed antimicrobial activity against E. coli, P. aeruginosa, S. aureus, and $S$. epidermidis [83]. In alginate beads, ZnO NPs/MPs had a snowflake shape at $<1 \mu \mathrm{m}$, which were evenly distributed with hydroxyapatite in alginate bead matrixes. Antimicrobial growth inhibition levels of $\mathrm{HA}-\mathrm{ZnO}-\mathrm{Alg}$ beads at $0.1 \mathrm{mg} / \mathrm{mL}$ were $56 \%$ against $E$. coli, $65 \%$ against $P$. aeruginosa, and $100 \%$ against S. aureus and S. epidermidis. 
Jose et al. [120] also reported growth inhibition of tungsten-doped polyethylene glycol (PEG)-capped $\mathrm{ZnO}$ (W-PEG-ZnO) NPs against E. coli and B. cereus, which were near-spherical at $\sim 40.46 \mathrm{~nm}$. Compared to ampicillin at $100 \mu \mathrm{g} / \mu \mathrm{L}$ inhibiting growth at $35 \mathrm{~mm}$ against $E$. coli and $20 \mathrm{~mm}$ against $B$. cereus, W-PEG-ZnO NPs showed a 5-6 mm zone of growth inhibition against $E$. coli at $400-600 \mu \mathrm{g} / \mu \mathrm{L}$ and a $6-8 \mathrm{~mm}$ zone of growth inhibition against $B$. cereus at $300-600 \mu \mathrm{g} / \mu \mathrm{L}$, suggesting $B$. cereus was more susceptible to W-PEG-ZnO NPs than E. coli.

Antimicrobial activity of biopolymer K-carrageenan-wrapped $\mathrm{ZnO}(\mathrm{KC}-\mathrm{ZnO}) \mathrm{NPs}$, oval-shaped at $97 \mathrm{~nm}$, was reported against MRSA [27]; the MIC level of KC-ZnO NPs was $7.5 \mu \mathrm{g} / \mathrm{mL}$. ZnO NP films manufactured with bacterial cellulose and propolis extract resulted in quasi-spherical ZnO NPs (70-90 nm), homogeneously distributed on the substrate surface in bacterial cellulose-ZnO NP-propolis extract (BC-ZnO-propolis) films [121]. The BC-ZnO-propolis films had antimicrobial activity against $E$. coli at an MIC level of $>1.89 \mathrm{mg} / \mathrm{mL}, B$. subtilis at 0.44 or $<0.44 \mathrm{mg} / \mathrm{mL}$, and C. albicans at $>0.8,1.3,1.89$, and $>1.89 \mathrm{mg} / \mathrm{mL}$, depending on $\mathrm{ZnO} N \mathrm{NP}$ types according to ultrasound frequency $(40 \mathrm{kHz}$ and $100 \mathrm{kHz})$ during the synthesis, and propolis extract contents $(3.5 \%, 7 \%, 11 \%$, and $15 \%, w t)$.

Curcumin in turmeric is known to have beneficial anti-inflammatory activity, and is used as a multipurpose nutraceutical in various dosage forms of tablets, capsules, and ointments [123]. After loading curcumin on $\mathrm{ZnO}(\mathrm{C}-\mathrm{ZnO}) \mathrm{NPs}$, the antimicrobial activity of C-ZnO NPs against E. coli, S. epidermis, S. aureus, and B. cereus was determined [124]. Among the $\mathrm{C}-\mathrm{ZnO} \mathrm{NPs}$, spheres (C-sZnO), rods (C-rZnO), javelin (C-jZnO), short petal nanoflowers (C-spZnO), and long petal nanoflowers (C-lpZnO) were detected with sizes of 40-100 nm, $600-900 \mathrm{~nm}$ ( $<300 \mathrm{~nm}$ of width), 300-600 nm ( $<300 \mathrm{~nm}$ of width), $2-4 \mu \mathrm{m}$, and $\sim 500 \mathrm{~nm}$, respectively. Their microbial growth inhibition levels were confirmed via measurements of well diffusion zones of inhibition as follows: C-sZnO, $8.4 \mathrm{~mm}$; C-rZnO, $10.1 \mathrm{~mm}$; C-jZnO, $11.1 \mathrm{~mm}$ (the highest); $\mathrm{C}-\mathrm{spZnO}, 8.1 \mathrm{~mm}$; C-lpZnO, $9.8 \mathrm{~mm}$; and curcumin, $7.4 \mathrm{~mm}$ (the lowest) against $E$. coli; C-sZnO, $19.1 \mathrm{~mm} ; \mathrm{C}-\mathrm{rZnO}, 17.2 \mathrm{~mm}$; C-jZnO, $19.4 \mathrm{~mm}$; C-spZnO, $16.4 \mathrm{~mm}$; C-lpZnO, $20.1 \mathrm{~mm}$ (the highest); and curcumin, $8.2 \mathrm{~mm}$ (the lowest) against S. epidermis; C-sZnO, $15.4 \mathrm{~mm}$; C-rZnO, $16.6 \mathrm{~mm}$; C-jZnO, $13.4 \mathrm{~mm}$; C-spZnO, $15.2 \mathrm{~mm}$; C-lpZnO, $17.0 \mathrm{~mm}$ (the highest); curcumin, $8.1 \mathrm{~mm}$ (the lowest) against $S$. aureus; and C-sZnO, $17.4 \mathrm{~mm}$; C-rZnO, C-jZnO, $18.7 \mathrm{~mm}$ (the highest); C-spZnO, $14.2 \mathrm{~mm}$; C-lpZnO, $14.2 \mathrm{~mm}$; and curcumin, $8.4 \mathrm{~mm}$ (the lowest) against $B$. cereus.

Graphene, graphene oxide (GO), and reduced GO (rGO) have also been studied as antibiotic agents in combinations of $\mathrm{ZnO}$ NPs with other biomaterials. Antimicrobial activity of graphene/ZnO nanocomposite films against Streptococcus mutans was reported by Kulshrestha et al. [84]. The ZnO NPs distributed in the graphene sheet films were near-spherical at 20-40 nm. The MIC level of graphene/ $\mathrm{ZnO}$ nanocomposite films was $125 \mu \mathrm{g} / \mathrm{mL}$. Oves et al. [85] described the antimicrobial activity of graphene/ZnO nanocomposites with curcumin against MRSA strains (ATCC 43300 and ATCC BAA-1708). In the nanocomposites, spherical ZnO NPs at $35 \mathrm{~nm}$ were homogenously distributed on graphene sheets. Compared to curcumin with an MIC of $125 \mu \mathrm{g} / \mathrm{mL}$, the graphene/ZnO nanocomposite induced growth inhibition at $125 \mu \mathrm{g} / \mathrm{mL}$ against MRSA ATCC 43300 and at $250 \mu \mathrm{g} / \mathrm{mL}$ against MRSA ATCC BAA-1708. Use of curcumin together with the graphene/ZnO nanocomposites achieved growth inhibition against MRSA ATCC 43300 and MRSA ATCC BAA-1708 at 31.25 and $62.5 \mu \mathrm{g} / \mathrm{mL}$, respectively. Against in vivo topical dermatitis infection, the growth of MRSA was inhibited by up to $64 \%$.

$\mathrm{GO} / \mathrm{ZnO}$ nanocomposites for wound care showed growth inhibition against $E$. coli, S. typhi, P. aeruginosa, and S. flexneri [86]. GO with smooth and wrinkled surface layers was used to prepare GO/ZnO nanocomposites. The ZnO NPs were well incorporated and distributed on the GO sheets generating agglomerates. Analysis of the zone of growth inhibition with $\mathrm{GO} / \mathrm{ZnO}$ nanocomposites at levels of $25-100 \mu \mathrm{g} / \mathrm{mL}$ under dark or visible light irradiation, showed that the composites were more susceptible to E. coli, P. aeruginosa, S. typhi, and S. flexneri than with GO alone. In addition, Wang et al. [87] reported 
antimicrobial activity against $E$. coli of $\mathrm{GO} / \mathrm{ZnO}$ composites, including rod-like $\mathrm{ZnO} \mathrm{NPs}$ at $4 \mathrm{~nm}$, homogenously attached on GO sheets. Using 1-4 $\mu \mathrm{g} \mathrm{GO} / \mathrm{ZnO}$ composites, growth inhibition zones were detected at 2 and $4 \mu \mathrm{g}$ (MIC, $2 \mu \mathrm{g}$ ).

In the case of rGO, combination of ZnO NPs with rGO had antimicrobial activity against microorganisms [88]. Spherical ZnO NPs at 100-300 nm were attached to rGO sheets for manufacturing $\mathrm{rGO} / \mathrm{ZnO}$ films with roughness at $159 \mathrm{~nm}$, containing homogenously distributed $\mathrm{ZnO}$ NPs on rGO sheets. They displayed $>99 \%(2-\log )$ growth reduction against S. aureus at $1 \%(\mathrm{wt}) \mathrm{rGO}$.

In cotton fabrics, $\mathrm{ZnO} N P$ s have been used as protective agents against textile degradation, unpleasant odor, and potential health risks caused by microbial growth after contact with the human body $[128,130,138]$. As an alternative to chemical biocides, ZnO NPs provide enhanced antimicrobial activity against pathogenic microorganisms in surfacemodified textiles during the manufacturing process. Noman, M.T. and M. Petrů [127] reported eight types of cotton- $\mathrm{ZnO} \mathrm{NP}(\mathrm{C}-\mathrm{nZnO})$ composites and their antimicrobial actions against $E$. coli and $S$. aureus. The $\mathrm{ZnO} N$ Ps were spherical at $27 \mathrm{~nm}$, and formed thick and dense layers on cotton surfaces in C-nZnO composites at $2.2 \%, 1.7 \%, 4.9 \%, 4.3 \%$, $11.1 \%, 7.8 \%, 22.2 \%$, and $16.7 \%(\mathrm{wt})$. They showed microbial growth reduction of $97-100 \%$ against $E$. coli and $96-98 \%$ against $S$. aureus. Subash et al. [129] also demonstrated microbial growth reduction by $\mathrm{ZnO} \mathrm{NP}$-coated fabric against $E$. coli and $S$. aureus. The $\mathrm{ZnO}$-coated fabric comprised evenly distributed spherical ZnO NPs $(200 \mathrm{~nm})$ on the fabric surface. In a $4.8 \mathrm{~cm}$-diameter circular cut of the fabric, E. coli and $S$. aureus growth levels were reduced by $80 \%$ and $99.99 \%$, respectively. In the case of $\mathrm{ZnO}$ MPs, they were coated on cotton fabrics together with chitosan and formed a uniformly distributed dense microstructure of rods showing antimicrobial growth inhibition against $E$. coli [126]. Immersion of $\mathrm{ZnCl}_{2}(4 \%)$ for $\mathrm{ZnO}$ MP synthesis on chitosan-loaded cotton fabrics (1-2\%/1 $\mathrm{g}$ cotton fabric) resulted in a growth inhibition zone of $2.5 \mathrm{~cm}$ in disk diffusion against $E$. coli.

\subsubsection{ZnO QDs}

$\mathrm{ZnO}$ QDs have been studied for imaging and therapy as theranostic agents having photoluminescence properties with antimicrobial activity against pathogenic microorganisms $[139,140]$. They have superior characteristics including high quantum yield, high stability, and a narrow emission range.

Based on different nanostructures of nanorods/nanotubes (ZnO QD-1, ZnO QD-2, and ZnO QD-12), nanospheres (ZnO QD-3, ZnO QD-4, ZnO QD-6, ZnO QD-7, ZnO QD-8, ZnO QD-10, ZnO QD-11, and ZnO QD-14), nanowhiskers (ZnO QD-5), nanoflowers, and mixtures of nanorods and nanoflowers ( $\mathrm{ZnO}$ QD-13) (ZnO QD-9: not mentioned), the growth inhibition levels of $14 \mathrm{ZnO}$ QDs were evaluated against $E$. coli, K. pneumonia, $P$. aeruginosa, S. aureus, L. monocytogenes, E. faecalis, E. aerogenes, B. anthracis, B. cereus, and S. epidermidis [89]. The lowest MIC levels among the $\mathrm{ZnO}$ QDs from $\mathrm{ZnO}-1$ to $\mathrm{ZnO}-10$ were as follows: $\mathrm{ZnO}$ QD-1, $25 \mathrm{mg} / \mathrm{mL}$ against E. coli; $\mathrm{ZnO}$ QD-4 and $\mathrm{ZnO}$ QD-6, $25 \mathrm{mg} / \mathrm{mL}$ against E. aerogenes; $\mathrm{ZnO} Q \mathrm{QD}-3$, and $\mathrm{ZnO}$ QD-5, $12.5 \mathrm{mg} / \mathrm{mL}$ against $K$. pneumonia; $\mathrm{ZnO}$ QD-3 and $\mathrm{ZnO}$ QD-7, $12.5 \mathrm{mg} / \mathrm{mL}$ against $P$. aeruginosa; $\mathrm{ZnO}$ QD-2, ZnO QD-3, and $\mathrm{ZnO}$ QD-8, $6.25 \mathrm{mg} / \mathrm{mL}$ against $B$. anthracis; $\mathrm{ZnO}$ QD-8, $6.25 \mathrm{mg} / \mathrm{mL}$ against $S$. aureus; $\mathrm{ZnO}$ QD-6 and ZnO QD-7, $50 \mathrm{mg} / \mathrm{mL}$ against L. monocytogenes; ZnO QD-2 and ZnO QD-7, 25 $\mathrm{mg} / \mathrm{mL}$ against $E$. faecalis; $\mathrm{ZnO}$ QD-3 and $\mathrm{ZnO} Q \mathrm{QD}-5,12.5 \mathrm{mg} / \mathrm{mL}$ against $B$. cereus; and $\mathrm{ZnO}$ QD-8, $1.5 \mathrm{mg} / \mathrm{mL}$ against $S$. epidermidis. Singh et al. [90] reported spherical $\mathrm{ZnO}$ QDs of $\sim 6 \mathrm{~nm}$ that showed an inhibition zone of $15.69 \mathrm{~mm}$ against E. coli. Compared to the growth inhibition level at $5 \mathrm{mM}$ of bulk zinc acetate, that of $\mathrm{ZnO}$ QDs against $E$. coli increased by 1.6-fold.

$\mathrm{ZnO}$ QDs are also functionalized with polymers, peptides, and antibiotic drugs [140-142]. Antimicrobial peptide (BSA-PEP-MPA) was attached to ZnO QDs (spheres, $104 \mathrm{~nm}$ ) containing vancomycin (Van@ZnO-BSA-PEP-MPA) and methicillin (Met@ZnO-BSA-PEP-MPA) for enhanced antimicrobial activity against S. aureus, B. subtilis, and MRSA [141]. Analysis of MIC levels showed that ZnO@BSA-PEP-MPA had no growth inhibition potential, used 
as a nanoprobe promoting permeability of antibiotics through microbial membrane. In the case of Van@ZnO-BSA-PEP-MPA, $2.0 \mu \mathrm{g} / \mathrm{mL}$ against $S$. aureus and $1.0 \mu \mathrm{g} / \mathrm{mL}$ against B. subtilis were detected as MIC levels. Growth inhibition at $6 \times 10^{4} \log (\mathrm{CFU} / \mathrm{g})$ was induced after administration of $4 \times 10^{8} \mathrm{CFU}$ of $S$. aureus for infection and $5.0 \mathrm{mg} / \mathrm{kg}$ of Van@ZnO-BSA-PEP-MPA as in vivo diagnostic agent with no changes in activity and body weight for theranostics. However, Met@ZnO-BSA-PEP-MPA showed $64 \mu \mathrm{g} / \mathrm{mL}$ of MIC against MRSA. Polyvinylprolidone-capped ZnO (PVP-ZnO) QDs also showed antimicrobial activity against E. coli O157:H7, S. enteritidis, and L. monocytogenes. Spherical ZnO QDs of $\sim 5 \mathrm{~nm}$ were used to prepare PVP-ZnO QDs, which were highly crystalline spheres at $4 \mathrm{~nm}(<\mathrm{ZnO}$ QDs) [142]. Compared to ZnO QDs at $1.12 \mathrm{mg} / \mathrm{mL}$ mediating growth inhibition of $63.9 \%$ against $S$. enteritidis and $80.6 \%$ against $L$. monocytogenes, PVP-ZnO QDs at $40 \mathrm{mg} / \mathrm{mL}$ showed growth inhibition of $66.7 \%$ against $E$. coli O157:H7 and $58.9 \%$ against L. monocytogenes. 
Table 2. Antimicrobial activity of zinc oxide $(\mathrm{ZnO})$ materials against pathogenic microorganisms.

\begin{tabular}{|c|c|c|c|c|c|}
\hline Materials & $\begin{array}{l}\text { Synthesis Techniques } \\
\text { (Precursor) }\end{array}$ & $\begin{array}{c}\text { Material Description } \\
\text { (Morphology/Particle Size) }\end{array}$ & $\begin{array}{l}\text { Antimicrobial Activity } \\
\text { Test Methods }\end{array}$ & $\begin{array}{c}\text { Antimicrobial Activity against Pathogenic } \\
\text { Microorganisms }\end{array}$ & Refs. \\
\hline \multicolumn{6}{|c|}{$\mathrm{ZnO}$ materials } \\
\hline \multirow{4}{*}{ OD structured $\mathrm{ZnO}$ NPs } & $\begin{array}{l}\text { Hydrothermal method or room } \\
\text { temperature synthesis } \\
\text { (zinc nitrate hexahydrate; zinc } \\
\text { sulfate; zinc acetate dihydrate) }\end{array}$ & $\begin{array}{l}\text { Spheres / } 12 \mathrm{~nm}, 25 \mathrm{~nm} \text {; } \\
30 \mathrm{~nm}, 88 \mathrm{~nm}, 142 \mathrm{~nm} \text {; } \\
212 \mathrm{~nm}, 307 \mathrm{~nm}\end{array}$ & Turbidity & $\begin{array}{l}6 \mathrm{mM}, \\
\text { [Staphylococcus aureus] } 30 \mathrm{~nm}: 10.11 \% \text { growth; } \\
88 \mathrm{~nm}: 54.34 \% \text { growth; } 142 \mathrm{~nm}: 78.12 \% \text { growth; } \\
212 \mathrm{~nm}: 79.79 \% \text { growth; } 307 \mathrm{~nm}: 96.67 \% \text { growth, } \\
\text { [Proteus vulgaris] } 12 \mathrm{~nm}: 8.71 \% \text { growth, } \\
\text { [Salmonella typhimurium] } 12 \mathrm{~nm}: 46.96 \% \text { growth, } \\
\text { [Shigella flexneri] } 12 \mathrm{~nm}: 5.95 \% \text { growth, [Bacillus } \\
\text { cereus] } 12 \mathrm{~nm}: 7.62 \% \text { growth }\end{array}$ & [16] \\
\hline & $\begin{array}{c}\text { Green method using Aloe vera } \\
\text { leaf extract (zinc acetate } \\
\text { dihydrate) }\end{array}$ & $\begin{array}{l}\text { ZnO-1 \& } \mathrm{ZnO}-2 \text { : hexagons } \\
\text { and spheres/ } 63 \mathrm{~nm} ; \sim 65 \mathrm{~nm} \text {, } \\
\text { and } 60-180 \mathrm{~nm} \\
\text { ZnO-3: cubes or rods } / 40- \\
45 \mathrm{~nm}\end{array}$ & $\begin{array}{l}\text { Well diffusion, broth } \\
\text { microdilution; MIC }\end{array}$ & $\begin{array}{c}\text { MIC, } \\
\text { [E. coli] ZnO-1, ZnO-2, and ZnO-3: } 1562 \mu \mathrm{g} / \mathrm{mL} \text {; } \\
\text { [S. aureus] ZnO-1: } 781 \mu \mathrm{g} / \mathrm{mL}, \mathrm{ZnO}-2 \text { and } \\
\text { ZnO-3: } 391 \mu \mathrm{g} / \mathrm{mL} \text {; [B. subtilis] } \mathrm{ZnO}-1 \text { and } \\
\text { ZnO-2: } 391 \mu \mathrm{g} / \mathrm{mL} \text {; ZnO-3: } 195 \mu \mathrm{g} / \mathrm{mL}\end{array}$ & [17] \\
\hline & $\begin{array}{l}\text { Precipitation method (zinc } \\
\text { acetate dihydrate) }\end{array}$ & $\begin{array}{l}\text { Nanopyramids/ } 15.4 \mathrm{~nm} \text { in } \\
\text { segments }\end{array}$ & $\begin{array}{l}\text { Colony counting, serial } \\
\text { dilution; MIC }\end{array}$ & $\begin{array}{l}\text { [Methicillin-resistant S. aureus (MRSA)] MIC, } \\
333 \mu \mathrm{g} / \mathrm{mL}(3 \log (\mathrm{CFU} / \mathrm{mL}) \text { inhibition at } \\
800 \mu \mathrm{g} / \mathrm{mL})\end{array}$ & [96] \\
\hline & $\begin{array}{l}\text { Soft chemical synthesis } \\
\quad(\text { micrometric } \mathrm{ZnO})\end{array}$ & $\begin{array}{l}\text { Spherical NP } \\
\text { cluster/cluster-590 nm; } \\
\text { NPs-63 nm }\end{array}$ & Colony counting & $\begin{array}{l}\text { Antimicrobial activity value of } \log \\
\quad \text { (control/sample), } \\
{[\text { E. coli }]>3.5 ;[\text { S. aureus }]>3.5}\end{array}$ & [19] \\
\hline \multirow{2}{*}{ 1D structured $\mathrm{ZnO}$ NPs } & $\begin{array}{l}\text { Hydrothermal method (zinc } \\
\text { acetate dihydrate) }\end{array}$ & $\begin{array}{l}\text { Hollow nanotubes / particle } \\
\text { size } 500 \mathrm{~nm} \text { in length; } \\
\text { surface area } 17.8 \mathrm{~m}^{2} / \mathrm{g} ; \\
\text { average pore size, } 278.6 \mathrm{~nm}\end{array}$ & Disk diffusion; MIC & $\begin{array}{c}\text { As-synthesized ZnO nanopowders, } \\
\text { MIC, } \\
\text { [Escherichia coli] } 0.0585 \mathrm{mg} / \mathrm{mL},[\text { S. aureus }] \\
0.234 \mathrm{mg} / \mathrm{mL},[\text { Pseudomonas aeruginosa] } \\
0.234 \mathrm{mg} / \mathrm{mL},[\text { Bacillus subtilis] } 0.938 \mathrm{mg} / \mathrm{mL}\end{array}$ & {$[54]$} \\
\hline & $\begin{array}{l}\text { Atomic layer deposition } \\
\text { process over polymer template } \\
\text { and template removal }\end{array}$ & $\begin{array}{l}\text { Hollow nanotubes/length, } \\
\sim 5 \mu \mathrm{m} \text {; thickness, } 59.5 \mathrm{~nm} \text {; } \\
\text { internal diameter, } 178.2 \mathrm{~nm}\end{array}$ & Colony counting & $\begin{array}{c}\text { ZnO nanotubes at } 1 \mathrm{wt} \% \text { with acrylic } \\
\text { polymer/extruded } \\
32 \mu \mathrm{m} \text {-polyethylene (PE) substrate film coating } \\
\left.[\text { E. coli }] 4.67 \mathrm{log} \text { reduction (cells } / \mathrm{cm}^{2}\right),[S . \\
\text { aureus }] 2.46 \mathrm{log} \text { reduction }\left(\text { cells } / \mathrm{cm}^{2} \text { ) }\right.\end{array}$ & [55] \\
\hline
\end{tabular}


Table 2. Cont.

\begin{tabular}{|c|c|c|c|c|c|}
\hline Materials & $\begin{array}{l}\text { Synthesis Techniques } \\
\text { (Precursor) }\end{array}$ & $\begin{array}{l}\text { Material Description } \\
\text { (Morphology/Particle Size) }\end{array}$ & $\begin{array}{l}\text { Antimicrobial Activity } \\
\text { Test Methods }\end{array}$ & $\begin{array}{c}\text { Antimicrobial Activity against Pathogenic } \\
\text { Microorganisms }\end{array}$ & Refs. \\
\hline & $\begin{array}{l}\text { Precipitation method (zinc } \\
\text { nitrate) }\end{array}$ & $\begin{array}{l}\text { Nanorods/88.7 nm using } \\
\text { 2-mercaptoethanol as a } \\
\text { capping agent }\end{array}$ & $\begin{array}{l}\text { Disk diffusion method, } \\
\text { serial dilution; MIC }\end{array}$ & [Klebsiella pneumoniae] MIC, $40 \mu \mathrm{g} / \mathrm{mL}$ & [99] \\
\hline & $\begin{array}{l}\text { Green method using Chlorella } \\
\text { vulgaris culture supernatant } \\
\text { (zinc acetate dihydrate) }\end{array}$ & $\begin{array}{l}\text { Nanorods/crystal size, } \\
3.4 \mathrm{~nm} \text {; length- } 150 \mathrm{~nm} \text {; } \\
\text { width- } 21 \mathrm{~nm} \text { (aspect ratio of } \\
\text { length to width } 7.14 \text { ) }\end{array}$ & Microdilution; MIC & $\begin{array}{c}\text { [E. coli, P. aeruginosa, S. aureus }] \\
\text { MIC, } 250 \mu \mathrm{g} / \mathrm{mL} \text { (excluding Enterococcus faecalis: } \\
\text { resistant to ZnO nanorods) }\end{array}$ & [100] \\
\hline & $\begin{array}{l}\text { Sol-gel method (zinc nitrate } \\
\text { hexahydrate) }\end{array}$ & Nanorods/500 nm-1 $\mu \mathrm{m}$ & Disk diffusion & $\begin{array}{c}\text { [Capping agent: ethylenediamine] E. } \\
\text { coli-inhibition, Micrococcus luteus-no inhibition, } \\
\text { [Capping agent: citric acid } \\
\text { monohydrate] E. coli-no inhibition, } B \text {. } \\
\text { subtilis-inhibition }\end{array}$ & [101] \\
\hline 2D structured $\mathrm{ZnO} \mathrm{NPs}$ & $\begin{array}{l}\text { Not available (conventional } \\
\text { products) }\end{array}$ & $\begin{array}{l}\text { ZnO-1: platelets } / 14.7 \mathrm{~nm} \\
\text { ZnO-2: platelets } / 17.5 \mathrm{~nm} \\
\text { ZnO-3: rods, } 76.2 \mathrm{~nm}\end{array}$ & $\begin{array}{l}\text { Disk diffusion, broth } \\
\text { dilution; MIC }\end{array}$ & $\begin{array}{c}\mathrm{ZnO}-1, \mathrm{ZnO}-2, \mathrm{ZnO}-3, \mathrm{MIC}(\mathrm{wt} \%) \\
{[\text { E. coli }] \text { 0.12, } 0.18,2.30 ;[\text { S. aureus }] \text { 0.25, } 0.30,3.40} \\
{[\text { P. aeruginosa }] 1.28,4.68,5.70 ;[\text { Candida albicans }]} \\
>8 ;>8 ;>8 ;[\text { Aspergillus brasiliensis }] \text { nil, nil, nil }\end{array}$ & {$[58]$} \\
\hline $\begin{array}{l}\text { 3D structured } \mathrm{ZnO} \mathrm{NP} \\
\text { network }\end{array}$ & $\begin{array}{l}\text { Sol-gel method (zinc } \\
\text { acetylacetonate hydrate) }\end{array}$ & $\begin{array}{l}\text { Spherical NP aggregate } \\
\text { network/aggregates: } \sim 3 \mu \mathrm{m} \text {; } \\
\text { NPs: } 48.3 \mathrm{~nm}\end{array}$ & $\begin{array}{c}\text { Colony counting; } \\
\text { photocatalytic incubation }\end{array}$ & $\begin{array}{c}\text { [E. coli }]\{\text { Dual UV for } 30 \mathrm{~s}\} \text { no particles- approx. } \\
\text { 2.8-3.0 } \log (\mathrm{CFU} / \mathrm{mL}), 0.05 \mathrm{mg} / \mathrm{mL}-\text { no colonies } \\
\text { detected }\end{array}$ & [18] \\
\hline ZnO NP mixtures & $\begin{array}{l}\text { Green method using Butea } \\
\text { monsoperma seed extract (zinc } \\
\text { nitrate hexahydrate) }\end{array}$ & Mixtures/25 nm & Broth dilution; MIC & $\begin{array}{l}\text { [P. aeruginosa (resistant to amikacin }(30 \mu \mathrm{g}) \text {, } \\
\text { cefepime }(30 \mu \mathrm{g}), \\
\text { sparfloxacin }(5 \mu \mathrm{g}), \text { piperacillin }(100 \mu \mathrm{g}), \\
\text { levofloxacin }(5 \mu \mathrm{g}), \text { piperacilin-tazobactum } \\
(100 / 10 \mu \mathrm{g}), \text { imipenem }(10 \mu \mathrm{g}), \text { tobramycin } \\
\quad(10 \mu \mathrm{g}), \text { nitrofurantoin }(300 \mu \mathrm{g}), \text { and } \\
\text { ceftazidime }(30 \mu \mathrm{g}))] \mathrm{MIC}, 1600 \mu \mathrm{g} / \mathrm{mL} ; \\
1600-3200 \mu \mathrm{g} / \mathrm{mL} \text { for isolates from patients }\end{array}$ & [102] \\
\hline \multirow[t]{2}{*}{$\mathrm{ZnO} \mathrm{MPs}$} & $\begin{array}{l}\text { Flame transport synthesis (zinc } \\
\text { microparticles) }\end{array}$ & Tetrapods/ 30 $\mu \mathrm{m}$ & Plaque assay & $\begin{array}{c}\text { [Herpes simplex virus type-2 (HSV-2)] } \mathrm{ZnO} \\
\text { tetrapod NP and HSV-2 cocktail for live virus } \\
\text { vaccine }\end{array}$ & {$[95,103]$} \\
\hline & $\begin{array}{l}\text { Green method using starch } \\
\text { (zinc acetate) }\end{array}$ & $\begin{array}{l}\text { Self-assembled hollow } \\
\text { microdonuts } / 1-2 \mu \mathrm{m}\end{array}$ & Disk diffusion & $\begin{array}{c}\text { [Enterobacter aerogenes and Staphylococcus } \\
\text { epidermidis] } 0.5-5 \mathrm{mM}\end{array}$ & [104] \\
\hline
\end{tabular}


Table 2. Cont.

\begin{tabular}{|c|c|c|c|c|c|}
\hline Materials & $\begin{array}{l}\text { Synthesis Techniques } \\
\text { (Precursor) }\end{array}$ & $\begin{array}{l}\text { Material Description } \\
\text { (Morphology/Particle Size) }\end{array}$ & $\begin{array}{l}\text { Antimicrobial Activity } \\
\text { Test Methods }\end{array}$ & $\begin{array}{c}\text { Antimicrobial Activity against Pathogenic } \\
\text { Microorganisms }\end{array}$ & Refs. \\
\hline \multicolumn{6}{|c|}{ Combinations of $\mathrm{ZnO}$ materials with drugs } \\
\hline $\begin{array}{l}\text { ZnO NPs with } \\
\text { azithromycin, gentamicin, } \\
\text { oxacillin, cefotaxime, } \\
\text { cefuroxime, fosfomycin, } \\
\text { chloramphenicol, and } \\
\text { oxytetracycline }\end{array}$ & $\begin{array}{l}\text { Green method using Ulva } \\
\text { fasciata alga extract } \\
\text { (zinc acetate dehydrate) }\end{array}$ & Flakes/length, $\sim 200 \mathrm{~nm}$ & Disk diffusion; MIC & $\begin{array}{l}\text { ZnO NPs: MIC, [E. coli, S. aureus, and } \\
\text { Salmonella enterica subsp. Bukuru] } 1.25 \mathrm{mg} \text { [C. } \\
\text { albicans] no inhibition } \\
\text { ZnO NPs ( } 10 \mathrm{mg} \text { ) with antibiotics: [E. } \\
\text { coli] azithromycin, oxacillin, cefotaxime, cefurox- } \\
\text { ime, fosfomycin, oxytetracycline-synergistic, [S. } \\
\text { aureus] azithromycin, cefotaxime, cefuroxime, } \\
\text { fosfomycin, chloramphenicol, oxytetracycline- } \\
\text { synergistic, [Salmonella spp.] oxacillin, cefuroxime, } \\
\text { fosfomycin-synergistic, azithromycin, gentam- } \\
\text { icin, cefotaxime, neomycin, ampicillin/sulbactam, } \\
\text { chloramphenicol, oxytetracycline-antagonistic }\end{array}$ & {$[20]$} \\
\hline $\begin{array}{l}\mathrm{ZnO} \text { with cephalexin } \\
\text { nanohybrids }\end{array}$ & $\begin{array}{l}\text { Ion exchange via sol-gel } \\
\text { method ( } \mathrm{ZnO} \text {, and } \\
\text { 2,4-chlorophenoxyacetic acid) }\end{array}$ & $\begin{array}{l}\text { Squeezed } \mathrm{ZnO} \text { crystals/not } \\
\text { available }\end{array}$ & Disk diffusion; MIC & $\begin{array}{l}\mathrm{ZnO} \text { with cephalexin nanohybrids: MIC, } \\
\text { [Aeromonas spp.] } 1 \mathrm{mg} / \mathrm{mL}\end{array}$ & [21] \\
\hline $\begin{array}{l}\text { ZnO NPs with } \beta \text {-lactam } \\
\text { antibiotics (ciprofloxacin } \\
\text { and imipenem) }\end{array}$ & $\begin{array}{l}\text { Not available (conventional } \\
\text { product) }\end{array}$ & Not available & $\begin{array}{l}\text { Disk diffusion; agar } \\
\text { dilution; MIC }\end{array}$ & $\begin{array}{l}\text { MIC } \\
\text { ZnO NPs: [E. coli] } 0.08 \mathrm{mg} / \mathrm{mL},[\text { K. pneumonia }] \\
0.05 \mathrm{mg} / \mathrm{mL} \\
\text { ZnO NPs with ciprofloxacin: } 0.2-1 \mathrm{mg} / \mathrm{mL} \\
\text { ZnO NPs with imipenem: decrease in antimi- } \\
\text { crobial effect (except for one K. pneumonia strain) }\end{array}$ & [79] \\
\hline
\end{tabular}


Table 2. Cont.

\begin{tabular}{|c|c|c|c|c|c|}
\hline Materials & $\begin{array}{l}\text { Synthesis Techniques } \\
\text { (Precursor) }\end{array}$ & $\begin{array}{c}\text { Material Description } \\
\text { (Morphology/Particle Size) }\end{array}$ & $\begin{array}{l}\text { Antimicrobial Activity } \\
\text { Test Methods }\end{array}$ & $\begin{array}{c}\text { Antimicrobial Activity against Pathogenic } \\
\text { Microorganisms }\end{array}$ & Refs. \\
\hline $\begin{array}{l}\text { ZnO NPs with ceftriaxone } \\
\text { (CFX-ZnO NPs), } \\
\text { ceftazidime (CFZ-ZnO } \\
\text { NPs), and gentamicin } \\
\text { (GTM-ZnO NPs) }\end{array}$ & $\begin{array}{l}\text { Green method using } \\
\text { Enterococcus faecalis culture } \\
\text { supernatant (zinc sulfate) }\end{array}$ & Spheres/15.3-37 nm & Broth dilution; MIC & $\begin{array}{l}\text { ZnO NPs: [E. coli, K. pneumonia, S. aureus, } \\
\text { E. faecalis, P. aeruginosa, and S. flexneri] MIC, } 4- \\
16 \mu \mathrm{g} / \mathrm{mL} \text { (P. aeruginosa }>64 \text { ) } \\
\text { Antibiotics: [E. coli, K. pneumonia, S. aureus, } \\
\text { E. faecalis, P. aeruginosa, and S. flexneri] MIC, 9- } \\
13 \mu \mathrm{g} / \mathrm{mL} \\
\mathbf{1} 24 \mathrm{~h} \text { incubation: [E. coli] CFX-ZnO NPs } 89-90 \% \\
\text { inhibition, [K. pneumonia] CFZ-ZnO NPs } 96-99 \% \\
\text { inhibition, [S. aureus] GTM-ZnO NPs } 95 \sim 98 \% \\
\text { inhibition, [E. faecalis] GTM-ZnO NPs } 95 \% \text { inhi- } \\
\text { bition, [P. aeruginosa] CFZ-ZnO NPs 3.8\% inhibi- } \\
\text { tion, [S. flexneri] CFZ-ZnO NPs } 96 \% \text { inhibition }\end{array}$ & [105] \\
\hline $\begin{array}{c}\text { ZnO NPs with } \\
\text { ampicillin/sulbactam }\end{array}$ & Milling method (zinc chloride) & Not available/25 nm & $\begin{array}{l}\text { Disk diffusion; broth } \\
\text { dilution; MIC }\end{array}$ & $\begin{array}{l}\text { MIC, } \\
\text { Ampicillin/sulbactam: [E. coli, S. typhi, and S. } \\
\text { aureus] } 50 \mu \mathrm{g} / \mathrm{mL} \text {, [K. pneumoniae, and P. aerugi- } \\
\text { nosa] } 100 \mu \mathrm{g} / \mathrm{mL} \\
\text { ZnO NPs: } 25-200 \mu \mathrm{g} \\
\text { ZnO NPs with ampicillin/sulbactam: [K. pneu- } \\
\text { moniae] } 25 \mu \mathrm{g}+100 \mu \mathrm{g} / \mathrm{mL} \text {, respectively } \\
\text { ZnO NP-ampicillin } / \text { sulbactam (conjugated } \\
\text { form): [K. pneumoniae] } 6.25 \mu \mathrm{g} / \mathrm{mL}\end{array}$ & [106] \\
\hline \multicolumn{6}{|c|}{ Combinations of $\mathrm{ZnO}$ materials with other metal oxide NPs/MPs, or metal doping } \\
\hline $\begin{array}{l}\mathrm{ZnO} \text { NPs with } \mathrm{TiO}_{2} \text { NPs in } \\
\text { 4A zeolite }\end{array}$ & $\begin{array}{l}\text { Ion exchange process } \\
\text { (zinc acetate dehydrate) }\end{array}$ & $\begin{array}{l}\text { Cubes/400-600 nm (NPs: } \\
\text { spheres, } \sim 50 \mathrm{~nm})\end{array}$ & Disk diffusion; MIC & $\begin{array}{c}\text { MIC, } \\
{[\text { E. coli O157:H7] } 1 \mathrm{mg} / \mathrm{mL},[\text { S. aureus }] 2 \mathrm{mg} / \mathrm{mL}} \\
{[\text { Pseudomonas fluorescens }] 1 \mathrm{mg} / \mathrm{mL},[\text { Listeria }} \\
\text { Monocytogenes }] 2 \mathrm{mg} / \mathrm{mL}\end{array}$ & {$[80]$} \\
\hline $\mathrm{Ag}-\mathrm{ZnO} \cdot \mathrm{mSiO}_{2}$ composites & $\begin{array}{l}\text { Precipitation of sodium water } \\
\text { glass in zinc acetate solution } \\
\text { (zinc acetate dihydrate) }\end{array}$ & $\begin{array}{c}\text { Lamellar porous } \\
\text { nanostructure with silver } \\
\text { spots/not available (specific } \\
\left.\text { surface area, } 250 \mathrm{~m}^{2} / \mathrm{g}\right)\end{array}$ & Microdilution; MIC & $\begin{array}{c}\text { MIC, }[\text { E. coli }] 2.9 \mathrm{mg} / \mathrm{cm}^{3},[\text { P. aeruginosa }] \\
3.9 \mathrm{mg} / \mathrm{cm}^{3},[\text { Streptococcus salivarius }] 5.9 \\
\mathrm{mg} / \mathrm{cm}^{3},[\text { S. aureus }] 5.9 \mathrm{mg} / \mathrm{cm}^{3},[\text { C. albicans }] \\
23.5 \mathrm{mg} / \mathrm{cm}^{3} \text { - synergistic }\end{array}$ & [81] \\
\hline
\end{tabular}


Table 2. Cont.

\begin{tabular}{|c|c|c|c|c|c|}
\hline Materials & $\begin{array}{l}\text { Synthesis Techniques } \\
\text { (Precursor) }\end{array}$ & $\begin{array}{c}\text { Material Description } \\
\text { (Morphology/Particle Size) }\end{array}$ & $\begin{array}{l}\text { Antimicrobial Activity } \\
\text { Test Methods }\end{array}$ & $\begin{array}{c}\text { Antimicrobial Activity against Pathogenic } \\
\text { Microorganisms }\end{array}$ & Refs. \\
\hline $\mathrm{ZnO}-\mathrm{SiO}_{2}$ composites & $\begin{array}{l}\text { Solid state mixing (zinc acetate } \\
\text { dihydrate) }\end{array}$ & $\begin{array}{l}\text { Nanostructures on the silica } \\
\text { surface/not available } \\
\text { NPs: nanorods } / 30-50 \\
\text { nm (specific surface area, } \\
\left.20-70 \mathrm{~m}^{2} / \mathrm{g}\right)\end{array}$ & Broth microdilution; MIC & $\begin{array}{c}\text { MIC, [S. aureus] } 2 \mathrm{mg} / \mathrm{mL} \text { (except for } \\
\mathrm{ZnO} / \mathrm{S}-\mathrm{S}-20, \mathrm{C}-\mathrm{A}-10 \text {, or C-A-20, }>2 \text { ) as } \\
0.228-0.632 \mathrm{mg} / \mathrm{mL} \text { of } \mathrm{ZnO} \text { NPs, [C. albicans] } 1 \\
\text { or } 2 \mathrm{mg} / \mathrm{mL}(\text { except for } \mathrm{ZnO} / \mathrm{S}-\mathrm{A}-10 \text { or S-S- } 10 \\
>2 \text { ) as } 0.187-0.632 \mathrm{mg} / \mathrm{mL} \text { of } \mathrm{ZnO} \text { NPs }\end{array}$ & [115] \\
\hline ZnO MPs with $\mathrm{TiO}_{2} \mathrm{MPs}$ & $\begin{array}{l}\text { Sol-gel method } \\
\text { (zinc chloride) }\end{array}$ & $\begin{array}{l}\text { ZnO MPs: near-spheres/ } \\
\text { 3.17-10.3 } \mu \mathrm{m} \\
\text { - } \mathrm{TiO}_{2} \mathrm{MP}: \text { near-spheres/ } \\
2.15-37.1 \mu \mathrm{m}\end{array}$ & $\begin{array}{c}\text { Broth dilution; MIC; } \\
\text { photocatalytic incubation } \\
\text { under visible light } \\
\text { irradiation }\end{array}$ & $\begin{array}{c}\mathrm{ZnO} \text { MPs }(0.25 \%) \text { with } \mathrm{TiO}_{2} \text { MPs }(1 \%):[\text { E. coli] } \\
76.8 \% \text { growth inhibition, }[\text { Streptococcus pyogenes] } \\
70.2 \% \text { growth inhibition, [K. pneumoniae] } 80.8 \% \\
\text { growth inhibition }\end{array}$ & [118] \\
\hline \multicolumn{6}{|c|}{ Combinations of $\mathrm{ZnO}$ materials with other biomaterials } \\
\hline \multicolumn{6}{|c|}{ Chitosan } \\
\hline $\begin{array}{l}\text { Chitosan-ZnO NP-loaded } \\
\text { gallic acid (C-ZnO@gal) } \\
\text { films }\end{array}$ & $\begin{array}{l}\text { Hydrothermal method } \\
\quad \text { (zinc sulfate) }\end{array}$ & $\begin{array}{l}\text { Z ZnO@gal NPs: near- } \\
\text { rods/ 19.2 nm } \\
\text { 口 C-ZnO@gal films: ho- } \\
\text { mogeneous distributed of } \\
\text { ZnO@gal NPs on chitosan } \\
\text { matrixes }(2 \mathrm{~g} \text { chitosan } / 70 \\
\text { mg ZnO@gal)/not available } \\
\text { (thickness } 0.10 \mathrm{~mm} \text { ) }\end{array}$ & Agar well diffusion & $\begin{array}{c}0.5 \mathrm{mg} / \mathrm{mL}, \\
{[\text { E. coli] } 28 \mathrm{~mm} \text { zone of inhibition, }} \\
\text { [B. subtilis] } 25 \mathrm{~mm} \text { zone of inhibition }\end{array}$ & [28] \\
\hline
\end{tabular}


Table 2. Cont.

\begin{tabular}{|c|c|c|c|c|c|}
\hline Materials & $\begin{array}{l}\text { Synthesis Techniques } \\
\text { (Precursor) }\end{array}$ & $\begin{array}{c}\text { Material Description } \\
\text { (Morphology/Particle Size) }\end{array}$ & $\begin{array}{l}\text { Antimicrobial Activity } \\
\text { Test Methods }\end{array}$ & $\begin{array}{c}\text { Antimicrobial Activity against Pathogenic } \\
\text { Microorganisms }\end{array}$ & Refs. \\
\hline $\begin{array}{l}\text { ZnO NP-containing } \\
\text { chitosan coating }\end{array}$ & $\begin{array}{l}\text { Not available (conventional } \\
\text { product: } 2 \% w / v \text { solution, } \\
10-30 \mathrm{~nm} \text { ) }\end{array}$ & $\begin{array}{l}\text { ZnO NPs: near-spheres/ } \\
\sim 65 \mathrm{~nm} \\
\mathbf{Z n O} \mathrm{NPs}(1 \%) \text { in chi- } \\
\text { tosan matrix }(2.5 \%) \text { for coat- } \\
\text { ing: polymeric matrixes in- } \\
\text { cluding uniformly distributed } \\
\text { ZnO NPs/not available }\end{array}$ & Broth dilution; MIC & $\begin{array}{c}{[\text { E. coli O157:H7] }} \\
\text { Chitosan }(2.5 \%, w / v): 2.5 \log (\mathrm{CFU} / \mathrm{g}) \\
\text { reduction at } 4{ }^{\circ} \mathrm{C} \\
\text { ZnO NP }(1 \%, w / v) \text {-containing chitosan }(2.5 \% \\
w / v): 2.8 \log (\mathrm{CFU} / \mathrm{g}) \text { reduction at } 4{ }^{\circ} \mathrm{C}\end{array}$ & [82] \\
\hline $\begin{array}{c}\text { ZnO NP-containing } \\
\text { chitosan/gelatin hybrid } \\
\text { nanocomposite } \\
\text { (nZnO-chitosan/gelatin) } \\
\text { films }\end{array}$ & $\begin{array}{l}\text { Green method using Cassia } \\
\text { fistula fruit extract (zinc nitrate } \\
\text { hexahydrate) }\end{array}$ & $\begin{array}{l}\text { ZnO NPs: polyhedrons, } \\
\text { quasi-spheres }(2 \% \text { in films), } \\
\text { rods }(4 \% \text { in films }) / 20-40 \mathrm{~nm} \text {, } \\
500-1000 \mathrm{~nm}, 200-400 \mathrm{~nm} \\
\text { n nZnO-chitosan/gelatin } \\
\text { films: evenly distributed NPs } \\
\text { on smooth, compact, and } \\
\text { heterogeneous surface } / \text { not } \\
\text { available (thickness } 86-92 \mu \mathrm{m})\end{array}$ & Disk diffusion & $\begin{array}{l}\text { [E. coli] ZnO NPs in films: } 1 \%-10.5 \mathrm{~mm} \text { zone of } \\
\text { inhibition, } 2 \%-10.5 \mathrm{~mm} \text { zone of inhibition, } \\
\quad 4 \%-10.7 \mathrm{~mm} \text { zone of inhibition } \\
\text { [S. aureus] not prominent compared to } E \text {. coli }\end{array}$ & [91] \\
\hline $\begin{array}{l}\text { 3D porous } \mathrm{ZnO} \\
\mathrm{NP} \text {-chitosan/silk/sericin } \\
\text { scaffolds for wound } \\
\text { dressing }\end{array}$ & $\begin{array}{l}\text { Not available (conventional } \\
\text { product: solution, } \sim 35 \mathrm{~nm} \text { ) }\end{array}$ & $\begin{array}{l}\text { Porous microstructures/not } \\
\text { available } \\
\text { (porosity } \sim 86 \% \text {; pore size } \\
4-200 \mu \mathrm{m} \text { ) }\end{array}$ & Disk diffusion & $\begin{array}{l}1.5 \times 1.5 \mathrm{~cm}^{2}, 2 \%(w / v) \text { chitosan, } 100 \mu \mathrm{L} \text { and } \\
250 \mu \mathrm{L} \text { of } \mathrm{ZnO} \text { NPs ( } 40 \mathrm{wt} \% \text { dispersion), } \\
\text { [E. coli] } 2-4.5 \mathrm{~mm} \text { zone of growth inhibition, [S. } \\
\text { aureus] } 2.5-5.5 \mathrm{~mm} \text { zone of growth inhibition }\end{array}$ & [136] \\
\hline $\begin{array}{l}\text { Chitosan-based } \mathrm{ZnO} \\
\text { nanocomposites }\end{array}$ & $\begin{array}{l}\text { Co-precipitation } \\
\text { (zinc acetate dihydrate) }\end{array}$ & $\begin{array}{l}\text { 口 } \mathrm{ZnO} \text { NPs: spheres } / 25-30 \\
\mathrm{~nm} \\
\mathbf{\square} \text { Chitosan-based } \mathrm{ZnO} \\
\text { nanocomposites for biodental } \\
\text { meterials: stars } / 20-25 \mathrm{~nm}\end{array}$ & Disc diffusion & $\begin{array}{c}\text { Zone of inhibition }(\mathrm{mm}), \\
{[\text { K. pneumoniae } 13 \mathrm{~mm} \text { (the highest) }>[\text { E. coli }]>} \\
{[\text { P. aeruginosa }]>[\text { B. subtillis }],[\text { S. aureus }], \text { and }} \\
{[\text { MRSA }] 6 \mathrm{~mm} \text { (the lowest) }}\end{array}$ & [137] \\
\hline
\end{tabular}


Table 2. Cont.

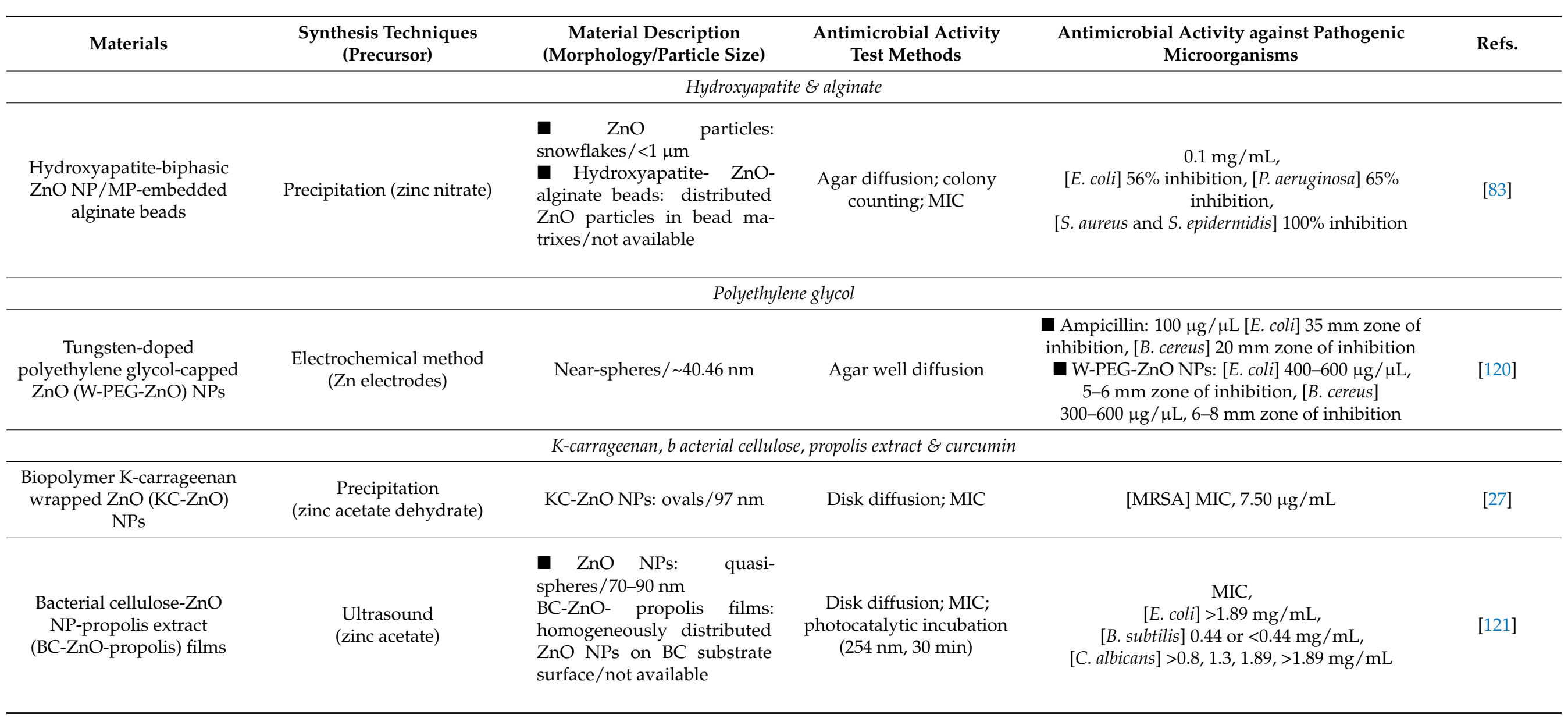


Table 2. Cont.

\begin{tabular}{|c|c|c|c|c|c|}
\hline Materials & $\begin{array}{l}\text { Synthesis Techniques } \\
\text { (Precursor) }\end{array}$ & $\begin{array}{l}\text { Material Description } \\
\text { (Morphology/Particle Size) }\end{array}$ & $\begin{array}{l}\text { Antimicrobial Activity } \\
\text { Test Methods }\end{array}$ & $\begin{array}{l}\text { Antimicrobial Activity against Pathogenic } \\
\text { Microorganisms }\end{array}$ & Refs. \\
\hline $\begin{array}{l}\text { Curcumin-loaded } \mathrm{ZnO} \\
\quad(\mathrm{C}-\mathrm{ZnO}) \mathrm{NPs}\end{array}$ & $\begin{array}{l}\text { Sol-gel method (zinc nitrate } \\
\text { hexahydrate) }\end{array}$ & $\begin{array}{l}\text { C-sZnO: spheres } / 40-100 \\
\text { nm } \\
\text { C-rZnO: rods/length, 600- } \\
900 \mathrm{~nm}(\text { width, }<300 \mathrm{~nm}) \\
\text { C C-jZnO: javelin/300-600 } \\
\text { nm (width, <300 nm) } \\
\text { 口 C-spZnO: short petal } \\
\text { nanoflower } / 2-4 \mu \mathrm{m} \\
\text { C-lpZnO: long petal } \\
\text { nanoflower/ 500 nm }\end{array}$ & $\begin{array}{l}\text { Well diffusion; colony } \\
\text { counting }\end{array}$ & $\begin{array}{c}\text { Zone of inhibition (mm), } \\
\text { [E. coli] C-sZnO, 8.4; C-rZnO, 10.1; C-jZnO, 11.1; } \\
\text { C-spZnO, 8.1; C-lpZnO, 9.8; C, 7.4 } \\
\text { [S. epidermis] C-sZnO, 19.1; C-rZnO, 17.2; } \\
\text { C-jZnO, 19.4; C-spZnO, 16.4; C-lpZnO, 20.1; C, } \\
\text { 8.2 } \\
\text { [S. aureus] C-sZnO, 15.4; C-rZnO, 16.6; C-jZnO, } \\
\text { 13.4; C-spZnO, 15.2; C-lpZnO, 17.0; C, 8.1 } \\
\text { [B. cereus] C-sZnO, 17.4; C-rZnO, 18.7; C-jZnO, } \\
\text { 18.7; C-spZnO, 14.2; C-lpZnO, 14.2; C, 8.4 }\end{array}$ & [124] \\
\hline \multicolumn{6}{|c|}{ Graphene, graphene oxide, E reduced graphene oxide } \\
\hline $\begin{array}{c}\text { Graphene/ } \mathrm{ZnO} \\
\text { nanocomposite films }\end{array}$ & $\begin{array}{l}\text { Ion exchange process } \\
\text { (zinc acetate) }\end{array}$ & $\begin{array}{l}\text { ZnO NPs: near-spheres/20- } \\
40 \mathrm{~nm} \\
\text { Graphene/ZnO nanocom- } \\
\text { posite films: ZnO NP- } \\
\text { distributed graphene sheet/not } \\
\text { available }\end{array}$ & Microdilution; MIC & [Streptococcus mutans] MIC, $125 \mu \mathrm{g} / \mathrm{mL}$ & [84] \\
\hline $\begin{array}{l}\text { Graphene/ZnO } \\
\text { nanocomposite with } \\
\text { curcumin }(\mathrm{C}-\mathrm{ZnO})\end{array}$ & $\begin{array}{l}\text { Ion exchange process } \\
\text { (zinc acetate dihydrate) }\end{array}$ & $\begin{array}{l}\text { ZnO NPs: spheres/35 nm } \\
\text { Graphene/ZnO: homoge- } \\
\text { nous distribution of ZnO NPs } \\
\text { on graphene sheet/not avail- } \\
\text { able }\end{array}$ & $\begin{array}{l}\text { Agar diffusion; colony } \\
\text { counting; microdilution; } \\
\text { MIC }\end{array}$ & $\begin{array}{l}\text { MIC, } \\
\text { Curcumin: } 125 \mu \mathrm{g} / \mathrm{mL} \\
\text { Graphene/ZnO: [MRSA ATCC 43300] } 125 \\
\mu \mathrm{g} / \mathrm{mL} \text {, [MRSA ATCC BAA-1708] 250 } \mu \mathrm{g} / \mathrm{mL} \\
\text { Graphene/C-ZnO: [MRSA ATCC } 43300] 31.25 \text {, } \\
\text { [MRSA ATCC BAA-1708] } 62.5 \mu \mathrm{g} / \mathrm{mL}(\sim 64 \% \text { in- } \\
\text { hibition of in vivo MRSA topical dermatitis in- } \\
\text { fection) }\end{array}$ & [85] \\
\hline
\end{tabular}


Table 2. Cont.

\begin{tabular}{|c|c|c|c|c|c|}
\hline Materials & $\begin{array}{l}\text { Synthesis Techniques } \\
\text { (Precursor) }\end{array}$ & $\begin{array}{l}\text { Material Description } \\
\text { (Morphology/Particle Size) }\end{array}$ & $\begin{array}{l}\text { Antimicrobial Activity } \\
\text { Test Methods }\end{array}$ & $\begin{array}{c}\text { Antimicrobial Activity against Pathogenic } \\
\text { Microorganisms }\end{array}$ & Refs. \\
\hline $\begin{array}{c}\text { Graphene oxide }(\mathrm{GO}) / \mathrm{ZnO} \\
\text { nanocomposite for wound } \\
\text { care }\end{array}$ & $\begin{array}{l}\text { Co-precipitation } \\
\text { (zinc nitrate) }\end{array}$ & $\begin{array}{l}\text { GO: smooth and wrinkled } \\
\text { surface layers/not available } \\
\text { GO/ZnO nanocomposite: } \\
\text { well incorporated and } \\
\text { distributed ZnO NPs }(0.1-0.4 \\
\text { M) on GO sheets forming } \\
\text { agglomerates/not available }\end{array}$ & $\begin{array}{c}\text { Disk diffusion, colony } \\
\text { counting; dark (D) and } \\
\text { visible light-irradiated (L) } \\
\text { conditions }\end{array}$ & $\begin{array}{c}\text { Zone of growth inhibition }(\mathrm{mm}) \\
\text { ZnO NPs }(0.4 \mathrm{M}) \text { on GO sheets, } 100 \mu \mathrm{g} / \mathrm{mL} \\
\text { [E. coli] GO-D, } 11 \mathrm{~mm} ; \mathrm{L}, 11.5 \mathrm{~mm} ; \mathrm{GO} / \mathrm{ZnO} \\
(0.4 \mathrm{M})-\mathrm{D}, 11 \mathrm{~mm} ; \mathrm{L}, 13 \mathrm{~mm} \\
\text { [P. aeruginosa] GO-D, } 10 \mathrm{~mm} ; \mathrm{L}, 10.5 \mathrm{~mm} ; \\
\mathrm{GO} / \mathrm{ZnO}(0.4 \mathrm{M})-\mathrm{D}, 10 \mathrm{~mm} ; \mathrm{L}, 13 \mathrm{~mm} \\
\text { [S. typhi] GO-D, } 10.5 \mathrm{~mm} ; \mathrm{L}, 9 \mathrm{~mm} ; \mathrm{GO} / \mathrm{ZnO} \\
(0.4 \mathrm{M})-\mathrm{D}, 11 \mathrm{~mm} ; \mathrm{L}, 11.5 \mathrm{~mm} \\
\text { [S. flexneri }] \mathrm{GO}-\mathrm{D}, 8 \mathrm{~mm} ; \mathrm{L}, 10.6 \mathrm{~mm} ; \mathrm{GO} / \mathrm{ZnO} \\
(0.4 \mathrm{M})-\mathrm{D}, 12 \mathrm{~mm} ; \mathrm{L}, 12.5 \mathrm{~mm}\end{array}$ & [86] \\
\hline $\mathrm{GO} / \mathrm{ZnO}$ composites & $\begin{array}{l}\text { Ion exchange process } \\
\text { (zinc acetate dihydrate) }\end{array}$ & $\begin{array}{l}\text { ZnO NPs: rods } / 4 \mathrm{~nm} \\
\text { GO/ZnO composites: ho- } \\
\text { mogeneously anchored } \mathrm{ZnO} \\
\text { NPs onto GO sheets/not } \\
\text { available }\end{array}$ & Agar disk diffusion; MIC & [E. coli] MIC, $2 \mu \mathrm{g}$ & [87] \\
\hline \multicolumn{6}{|c|}{ Cotton fabric } \\
\hline $\begin{array}{c}\text { ZnO MPs-loaded } \\
\text { chitosan-coated cotton } \\
\text { fabrics }\end{array}$ & $\begin{array}{l}\text { Precipitation } \\
\text { (zinc chloride) }\end{array}$ & $\begin{array}{l}\text { Uniformly distributed dense } \\
\text { microstructure of rods / not } \\
\text { available }\end{array}$ & Disk diffusion & $\begin{array}{c}\text { [E. coli] } 2.5 \mathrm{~cm} \text { zone of growth inhibition }\left(\mathrm{ZnCl}_{2}\right. \\
4 \% \text {, chitosan } 1-2 \% / 1 \mathrm{~g} \text { cotton fabric) }\end{array}$ & [126] \\
\hline
\end{tabular}


Table 2. Cont.

\begin{tabular}{|c|c|c|c|c|c|}
\hline Materials & $\begin{array}{l}\text { Synthesis Techniques } \\
\text { (Precursor) }\end{array}$ & $\begin{array}{l}\text { Material Description } \\
\text { (Morphology/Particle Size) }\end{array}$ & $\begin{array}{l}\text { Antimicrobial Activity } \\
\text { Test Methods }\end{array}$ & $\begin{array}{c}\text { Antimicrobial Activity against Pathogenic } \\
\text { Microorganisms }\end{array}$ & Refs. \\
\hline $\begin{array}{l}\text { Cotton-ZnO NP composites } \\
\text { (C-nZnO) }\end{array}$ & $\begin{array}{l}\text { Precipitation } \\
\text { (zinc chloride) }\end{array}$ & $\begin{array}{l}\text { ZnO NPs: quasi- } \\
\text { spheres/27 nm } \\
\text { C-nZnO composites ( } 8 \\
\text { types): thick condense layers } \\
\text { of } \mathrm{ZnO} \text { NPs on cotton sur- } \\
\text { faces/not available }\end{array}$ & $\begin{array}{l}\text { Disk diffusion; colony } \\
\text { counting }\end{array}$ & $\begin{array}{c}\text { nZnO amounts in C-nZnO: } 2.2,1.7,4.9,4.3,11.1 \text {, } \\
\quad 7.8,22.2 \text {, and } 16.7 \mathrm{wt} \% \\
9 \mathrm{~mm} \text { in diameter, [E. coli] } 97-100 \% \text { growth } \\
\text { reduction, [S. aureus] } 96-98 \% \text { growth reduction }\end{array}$ & [127] \\
\hline ZnO NP-coated fabric & $\begin{array}{l}\text { Green method using starch } \\
\text { (zinc nitrate) }\end{array}$ & $\begin{array}{l}\text { ZnO NPs: spheres/200 nm } \\
\text { ZnO NP-coated fabric: } \\
\text { evenly distributed ZnO NPs } \\
\text { on fabric surface/not avail- } \\
\text { able }\end{array}$ & Colony counting & $\begin{array}{l}4.8 \mathrm{~cm} \text { in diameter of fabric, } \\
{[\text { E. coli] } 80 \% \text { reduction }} \\
\text { [S. aureus] } 99.99 \% \text { reduction }\end{array}$ & [129] \\
\hline \multicolumn{6}{|c|}{$\mathrm{ZnO}$ quantum dots (QDs) } \\
\hline $\begin{array}{c}\text { Different } \\
\text { nanostructure-based } \mathrm{ZnO} \\
\text { QDs (ZnO QD-1-ZnO } \\
\text { QD-14) }\end{array}$ & $\begin{array}{c}\text { Sol-gel method } \\
\text { (zinc acetate dihydrate) }\end{array}$ & $\begin{array}{l}\text { Nanorods, nanotubes, } \\
\text { nanospheres, nanowhiskers, } \\
\text { nanoflowers/not available }\end{array}$ & $\begin{array}{l}\text { Agar well diffusion; agar } \\
\text { dilution; MIC }\end{array}$ & $\begin{array}{c}\text { MIC, } \\
\text { [E. coli] ZnO QD-1: } 25 \mathrm{mg} / \mathrm{mL}, \\
\text { [Enterobacter aerogenes] ZnO QD-4 and ZnO } \\
\text { QD-6: } 25 \mathrm{mg} / \mathrm{mL}, \\
\text { mg/mL, } \\
\text { [K. pneumonia] ZnO QD-3 and ZnO QD-5: } 12.5 \\
\text { mg/mL, } \\
\text { [P. aeruginosa] ZnO QD-3 and ZnO QD-7: } 12.5 \\
\text { [Bacillus anthracis] ZnO QD-2, ZnO QD-3 and } \\
\text { ZnO QD-8: } 6.25 \mathrm{mg} / \mathrm{mL}, \\
\text { [S. aureus] ZnO QD-8: } 6.25 \mathrm{mg} / \mathrm{mL}, \\
\text { [L. monocytogenes] ZnO QD-6 and ZnO QD-7: } 50 \\
\text { mg/mL, } \\
\text { [E. faecalis] ZnO QD-2 and ZnO QD-7: } 25 \\
\text { mg/mL, } \\
\text { [B. cereus] ZnO QD-3 and ZnO QD-5: } 12.5 \\
\text { mg/mL, } \\
\text { [S. epidermidis] ZnO QD-8: } 1.5 \text { mg/mL }\end{array}$ & [89] \\
\hline
\end{tabular}


Table 2. Cont.

\begin{tabular}{|c|c|c|c|c|c|}
\hline Materials & $\begin{array}{l}\text { Synthesis Techniques } \\
\text { (Precursor) }\end{array}$ & $\begin{array}{c}\text { Material Description } \\
\text { (Morphology/Particle Size) }\end{array}$ & $\begin{array}{l}\text { Antimicrobial Activity } \\
\text { Test Methods }\end{array}$ & $\begin{array}{c}\text { Antimicrobial Activity against Pathogenic } \\
\text { Microorganisms }\end{array}$ & Refs. \\
\hline ZnO QDs & $\begin{array}{c}\text { Green method using Eclipta alba } \\
\text { leaf extract } \\
\text { (zinc acetate dihydrate) }\end{array}$ & Spheres/ 6 nm & Agar diffusion & $\begin{array}{l}{[\text { E. coli }] 15.69 \mathrm{~mm} \text { zone of inhibition (1.6-fold }} \\
\text { increase compared to bulk zinc acetate at } 5 \mathrm{mM})\end{array}$ & [90] \\
\hline $\begin{array}{c}\text { Antimicrobial } \\
\text { peptide-based ZnO QDs } \\
\text { containing vancomycin and } \\
\text { methicillin } \\
\text { (Van@ZnO-BSA-PEP-MPA; } \\
\text { Met@ZnO-BSA-PEP-MPA) }\end{array}$ & $\begin{array}{l}\text { Precipitation } \\
\text { (zinc acetate) }\end{array}$ & $\begin{array}{l}\text { ZnO@BSA-PEP-MPA: } \\
\text { spheres/104 nm }\end{array}$ & $\begin{array}{l}\text { Broth dilution; MIC; in vivo } \\
\text { diagnostics- } 4 \times 10^{8} \text { CFU S. } \\
\text { aureus for infection and } \\
\text { Van@ZnO-BSA-PEP-MPA } \\
\text { at } 5.0 \mathrm{mg} / \mathrm{kg} \text { for } \\
\text { theranostics }\end{array}$ & $\begin{array}{l}\text { MIC, } \\
\text { Z ZnO@BSA-PEP-MPA: no inhibition } \\
\text { (nanoprobe) } \\
\text { 口 Van@ZnO-BSA-PEP- MPA: [S. aureus] } 2.0 \\
\mu \mathrm{g} / \mathrm{mL} \text {, [B. subtilis] } 1.0 \mu \mathrm{g} / \mathrm{mL} \text { (in vivo diagnos- } \\
\text { tics: no changes in activity and body weight, } 6 \\
\times 10^{4} \text { log (CFU/g) growth inhibition) } \\
\text { - Met@ZnO-BSA-PEP-MPA: [MRSA] } 64 \mu \mathrm{g} / \mathrm{mL}\end{array}$ & [141] \\
\hline $\begin{array}{c}\text { Polyvinylpyrrolidone- } \\
\text { capped ZnO (PVP-ZnO) } \\
\text { QDs }\end{array}$ & $\begin{array}{c}\text { Precipitation } \\
\text { (zinc acetate hydrate) }\end{array}$ & $\begin{array}{l}\text { ZnO QDs: spheres/ } 5 \mathrm{~nm} \\
\text { PVP-ZnO QDs: highly } \\
\text { crystalline spheres/ 4 nm } \\
\text { (smaller than ZnO QDs) }\end{array}$ & $\begin{array}{l}\text { Agar diffusion; colony } \\
\text { counting }\end{array}$ & $\begin{array}{l}\text { 1. } \mathrm{ZnO} \text { QDs }(1.12 \mathrm{mg} / \mathrm{mL}): \text { [S. Enteritidis] } \\
\text { 63.9\% growth inhibition, [L. monocytogenes] } \\
\text { 80.6\% growth inhibition } \\
\text { 2. PVP-ZnO QDs }(40 \mathrm{mg} / \mathrm{mL}): \text { [E. coli } \\
\text { O157:H7] 66.7\% growth inhibition, [L. } \\
\text { monocytogenes] } 58.9 \% \text { growth inhibition }\end{array}$ & [142] \\
\hline
\end{tabular}




\section{Current Biomedical Applications}

$\mathrm{ZnO}$ NPs/MPs are one of Zn-based materials that have been extensively used in various biomedical fields including antibiotic therapy, medical devices, theranostics, tissue engineering, and health care because of their antimicrobial functions against pathogenic microorganisms (Figure 2) [11,143-148]. In the human body, Zn plays a pivotal role in life cycle maintenance and $\mathrm{Zn}$ deficiency causes cell impairment and malignancy leading to severe diseases related to immune responses such as infection and cancer [69]. As a first aid antibiotic alternative for the protection of skin [143,147], ZnO ointment (40\%) or cream $(10 \%)$ is conventionally used. In addition, ZnO NPs/MPs and antibiotic drugs are applied as endo dressing in paste forms [107]. They are also used as $\mathrm{ZnO}$ surgical adhesives in medical devices [144,145]. Moreover, ZnO NPs/MPs have been utilized as postoperative dressing on leg excisions [148]. In theranostics, biocompatible $\mathrm{ZnO}$ QDs are explored as photodynamic therapeutics as well as diagnostic agents owing to their photoluminescence properties based on photochemical stability [11]. For dental tissue engineering, $\mathrm{ZnO}$ NPs/MPs are used as coating agents in orthopedic and dental implants [146]. ZnO NPs/MPs and eugenol are also extensively used as temporary cement for dental implants [108]. ZnO waxes or sunscreen lotions are used as health care products for skin protection against acne/blemish or UV and visible light $[149,150]$. Although ZnO NPs/MPs still have exposure risks to health via the inhalation route [151,152], $\mathrm{ZnO}$ is considered as "generally recognized as safe" and is approved by the U.S. Food and Drug Administration and the health risks of $\mathrm{ZnO}$ NPs/MPs are guided by the Organisation for Economic Co-operation and Development, based on their unique physicochemical characteristics via synthesis techniques [153]. Therefore, $\mathrm{ZnO}$ NPs/MPs have a promising potential for use in biomedical applications including medicine, medical devices, and cosmeceuticals connected with antibiotic functions overcoming drug resistance.

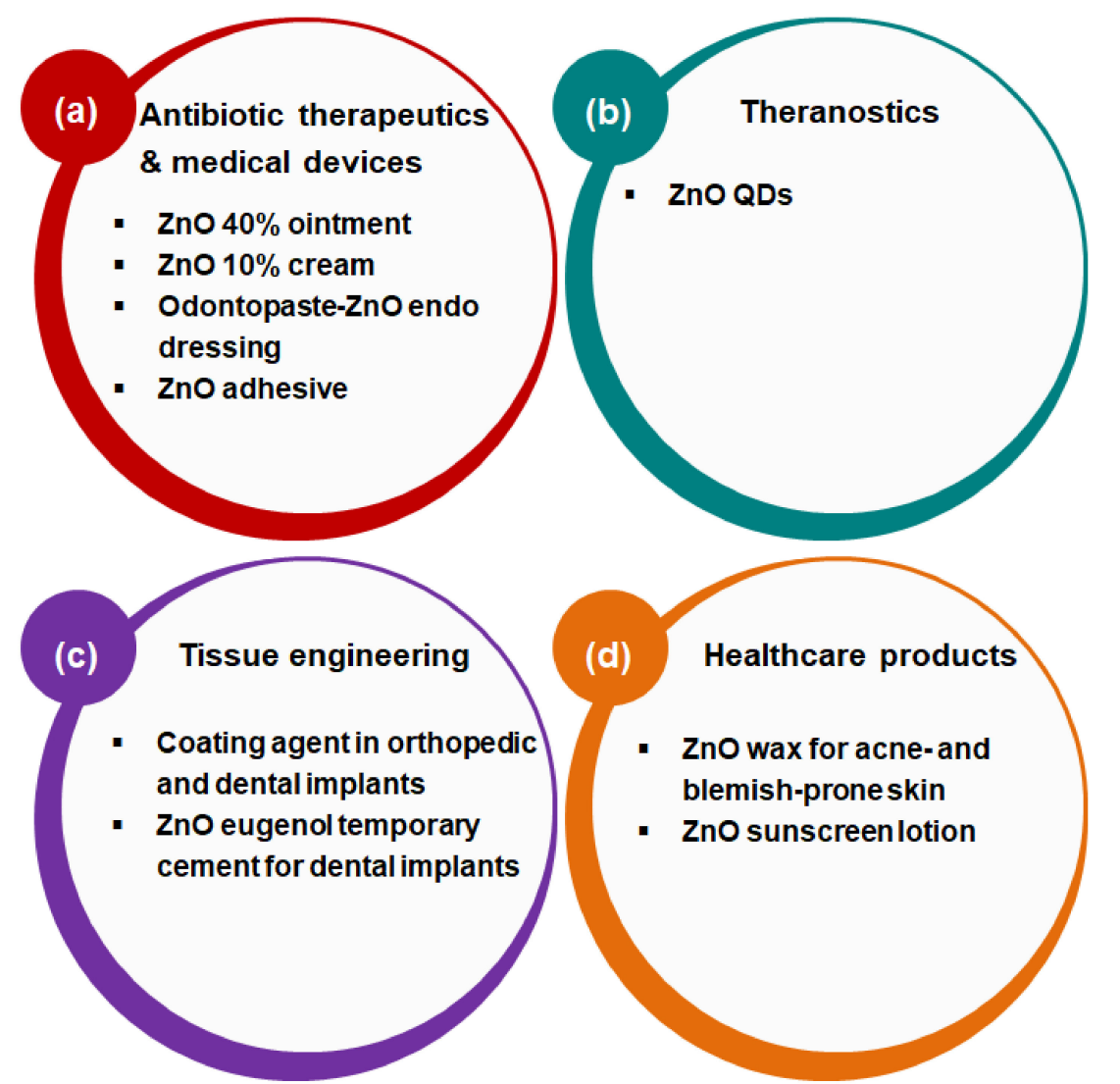

Figure 2. Functional approaches of $\mathrm{ZnO}$ materials for biomedical applications: (a) antibiotic therapeutics and medical devices, (b) theranostics, (c) tissue engineering, and (d) healthcare products. 


\section{Conclusions}

The antibiotic properties of $\mathrm{ZnO}$ materials have been highlighted for their biomedical applications in combating multi-drug resistance. Compared to currently available antibiotic drugs, they exhibit different mechanisms of antimicrobial actions; these mechanisms are mainly induced by the $\mathrm{Zn}^{2+}$ ion, particle adsorption, ROS generation and photocatalytic responses based on physicochemical characteristics of these materials, which vary substantially according to their synthesis techniques. ZnO NPs, sometimes MPs, show enhanced antimicrobial performance even toward pathogenic viruses. Their combinations with other antibiotic drugs, metal oxide NPs/MPs or metal doping, and other biomaterials also have a wide-spectrum antimicrobial activity that can be customized for multi-therapeutic options and used to improve their applicability as industrial and clinical translation platforms. Moreover, $\mathrm{ZnO}$ QDs display enhanced antimicrobial actions as theranostic agents. Therefore, $\mathrm{ZnO}$ materials can be a next-generation antibiotic drug against multi-drug resistant pathogenic microorganisms and, in the near future, combinations of these can be developed further with industrial and clinical impacts.

Author Contributions: Conceptualization, S.-E.J. and H.-E.J.; investigation, S.-E.J. and H.-E.J.; writing—original draft preparation, S.-E.J.; writing—review and editing, S.-E.J. and H.-E.J.; supervision, S.-E.J. and H.-E.J. All authors have read and agreed to the published version of the manuscript.

Funding: This research received no external funding.

Conflicts of Interest: The authors declare no conflict of interest.

$\begin{array}{ll}\text { Abbreviations } & \\ \text { BC } & \text { Bacterial cellulose } \\ \text { BSA } & \text { Bovine serum albumin } \\ \text { CFU } & \text { Colony forming unit } \\ \text { CFX } & \text { Ceftriaxone } \\ \text { CFZ } & \text { Ceftazidime } \\ \text { C-jZnO } & \text { Curcumin-loaded ZnO javelin } \\ \text { C-lpZnO } & \text { Curcumin-loaded long petal zno nanoflower } \\ \text { C-nZnO } & \text { Cotton-ZnO nanoparticle nanocomposite } \\ \text { C-rZnO } & \text { Curcumin-loaded ZnO rod } \\ \text { C-spZnO } & \text { Curcumin-loaded short petal zno nanoflower } \\ \text { C-sZnO } & \text { Curcumin-loaded ZnO sphere } \\ \text { C-ZnO } & \text { Curcumin-loaded ZnO } \\ \text { C-ZnO@gal } & \text { Chitosan-ZnO nanoparticle-loaded gallic acid } \\ \text { D } & \text { Dark } \\ \text { GO } & \text { Graphene oxide } \\ \text { GTM } & \text { Gentamicin } \\ \text { HA-ZnO-Alg } & \text { Hydroxyapatite-biphasic ZnO nanoparticle/microparticle- } \\ & \text { embedded alginate } \\ \text { HSV-2 } & \text { Herpes simplex virus type-2 } \\ \text { KC } & \text { K-carrageenan } \\ \text { L } & \text { Light } \\ \text { Met } & \text { Methicillin } \\ \text { MIC } & \text { Minimum inhibitory concentration } \\ \text { MPs } & \text { Microparticles } \\ \text { MRSA } & \text { Methicillin-resistant staphylococcus aureus } \\ \text { nZnO-chitosan/gelatin } & \text { ZnO NP-containing chitosan/gelatin hybrid nanocomposite } \\ \text { PE } & \text { Polyethylene } \\ \text { PVP } & \text { Polyvinylpyrrolidone } \\ & \end{array}$




$\begin{array}{ll}\text { QDs } & \text { Quantum dots } \\ \text { rGO } & \text { Reduced graphene oxide } \\ \text { UV } & \text { Ultraviolet } \\ \text { Van } & \text { Vancomycin } \\ \text { W-PEG-ZnO } & \text { Tungsten-doped polyethylene glycol-capped ZnO }\end{array}$

\section{References}

1. Makabenta, J.M.V.; Nabawy, A.; Li, C.-H.; Schmidt-Malan, S.; Patel, R.; Rotello, V.M. Nanomaterial-based therapeutics for antibiotic-resistant bacterial infections. Nat. Rev. Microbiol. 2020. [CrossRef] [PubMed]

2. Muzammil, S.; Hayat, S.; Fakhar, E.A.M.; Aslam, B.; Siddique, M.H.; Nisar, M.A.; Saqalein, M.; Atif, M.; Sarwar, A.; Khurshid, A.; et al. Nanoantibiotics: Future nanotechnologies to combat antibiotic resistance. Front. Biosci. 2018, 10, 352-374. [CrossRef]

3. da Silva, B.L.; Abuçafy, M.P.; Berbel Manaia, E.; Oshiro Junior, J.A.; Chiari-Andréo, B.G.; Pietro, R.C.R.; Chiavacci, L.A. Relationship Between Structure And Antimicrobial Activity Of Zinc Oxide Nanoparticles: An Overview. Int. J. Nanomed. 2019, 14, 9395-9410. [CrossRef] [PubMed]

4. Dizaj, S.M.; Lotfipour, F.; Barzegar-Jalali, M.; Zarrintan, M.H.; Adibkia, K. Antimicrobial activity of the metals and metal oxide nanoparticles. Mater. Sci. Eng. C 2014, 44, 278-284. [CrossRef] [PubMed]

5. Jin, S.-E.; Jin, H.-E. Synthesis, Characterization, and Three-Dimensional Structure Generation of Zinc Oxide-Based Nanomedicine for Biomedical Applications. Pharmaceutics 2019, 11, 575. [CrossRef] [PubMed]

6. Ul Haq, A.N.; Nadhman, A.; Ullah, I.; Mustafa, G.; Yasinzai, M.; Khan, I. Synthesis Approaches of Zinc Oxide Nanoparticles: The Dilemma of Ecotoxicity. J. Nanomater. 2017, 2017, 8510342. [CrossRef]

7. Sánchez-López, E.; Gomes, D.; Esteruelas, G.; Bonilla, L.; Lopez-Machado, A.L.; Galindo, R.; Cano, A.; Espina, M.; Ettcheto, M.; Camins, A.; et al. Metal-Based Nanoparticles as Antimicrobial Agents: An Overview. Nanomaterials 2020, 10, 292. [CrossRef]

8. Van Giau, V.; An, S.S.A.; Hulme, J. Recent advances in the treatment of pathogenic infections using antibiotics and nano-drug delivery vehicles. Drug Des. Dev. Ther. 2019, 13, 327-343. [CrossRef]

9. Bajwa, N.; Mehra, N.K.; Jain, K.; Jain, N.K. Pharmaceutical and biomedical applications of quantum dots. Artif. Cells Nanomed. Biotechnol. 2016, 44, 758-768. [CrossRef]

10. Khan, S.T.; Musarrat, J.; Al-Khedhairy, A.A. Countering drug resistance, infectious diseases, and sepsis using metal and metal oxides nanoparticles: Current status. Colloids Surf. B Biointerfaces 2016, 146, 70-83. [CrossRef]

11. Martínez-Carmona, M.; Gun'ko, Y.; Vallet-Regí, M. ZnO Nanostructures for Drug Delivery and Theranostic Applications. Nanomaterials 2018, 8, 268. [CrossRef] [PubMed]

12. Pelgrift, R.Y.; Friedman, A.J. Nanotechnology as a therapeutic tool to combat microbial resistance. Adv. Drug Deliv. Rev. 2013, 65, 1803-1815. [CrossRef] [PubMed]

13. Czyżowska, A.; Barbasz, A. A review: Zinc oxide nanoparticles-Friends or enemies? Int. J. Environ. Health Res. 2020. [CrossRef]

14. Sirelkhatim, A.; Mahmud, S.; Seeni, A.; Kaus, N.H.M.; Ann, L.C.; Bakhori, S.K.M.; Hasan, H.; Mohamad, D. Review on Zinc Oxide Nanoparticles: Antibacterial Activity and Toxicity Mechanism. Nano-micro Lett. 2015, 7, 219-242. [CrossRef] [PubMed]

15. Yu, Z.; Li, Q.; Wang, J.; Yu, Y.; Wang, Y.; Zhou, Q.; Li, P. Reactive Oxygen Species-Related Nanoparticle Toxicity in the Biomedical Field. Nanoscale Res. Lett. 2020, 15, 115. [CrossRef] [PubMed]

16. Raghupathi, K.R.; Koodali, R.T.; Manna, A.C. Size-Dependent Bacterial Growth Inhibition and Mechanism of Antibacterial Activity of Zinc Oxide Nanoparticles. Langmuir 2011, 27, 4020-4028. [CrossRef]

17. Sharma, S.; Kumar, K.; Thakur, N.; Chauhan, S.; Chauhan, M.S. The effect of shape and size of ZnO nanoparticles on their antimicrobial and photocatalytic activities: A green approach. Bull. Mater. Sci. 2019, 43, 20. [CrossRef]

18. Jin, S.E.; Jin, J.E.; Hwang, W.; Hong, S.W. Photocatalytic antibacterial application of zinc oxide nanoparticles and self-assembled networks under dual UV irradiation for enhanced disinfection. Int. J. Nanomed. 2019, 14, 1737-1751. [CrossRef]

19. de Lucas-Gil, E.; Leret, P.; Monte-Serrano, M.; Reinosa, J.J.; Enríquez, E.; Del Campo, A.; Cañete, M.; Menéndez, J.; Fernández, J.F.; Rubio-Marcos, F. ZnO Nanoporous Spheres with Broad-Spectrum Antimicrobial Activity by Physicochemical Interactions. ACS Appl. Nano Mater. 2018, 1, 3214-3225. [CrossRef]

20. Abo-Shama, U.H.; El-Gendy, H.; Mousa, W.S.; Hamouda, R.A.; Yousuf, W.E.; Hetta, H.F.; Abdeen, E.E. Synergistic and Antagonistic Effects of Metal Nanoparticles in Combination with Antibiotics Against Some Reference Strains of Pathogenic Microorganisms. Infect. Drug Resist. 2020, 13, 351-362. [CrossRef]

21. Al-Hisnawi, M.S.; Jabor, M.A. Preparation of nanohybrid compound from the drugs (naproxen and cephalexin) with zinc oxide and studying biological activities against Aeromonas bacteria. J. Contemp. Med. Sci. 2016, 1, 16-19.

22. Bian, Z.; Tachikawa, T.; Zhang, P.; Fujitsuka, M.; Majima, T. A nanocomposite superstructure of metal oxides with effective charge transfer interfaces. Nat. Commun. 2014, 5, 3038. [CrossRef] [PubMed]

23. Shanmugam, N.R.; Muthukumar, S.; Prasad, S. A review on ZnO-based electrical biosensors for cardiac biomarker detection. Future Sci. OA 2017, 3, FSO196. [CrossRef] [PubMed]

24. Stankic, S.; Suman, S.; Haque, F.; Vidic, J. Pure and multi metal oxide nanoparticles: Synthesis, antibacterial and cytotoxic properties. J. Nanobiotechnol. 2016, 14, 73. [CrossRef] [PubMed]

25. Giannossa, L.; Longano, D.; Ditaranto, N.; Nitti, M.; Paladini, F.; Pollini, M.; Rai, M.; Sannino, A.; Valentini, A.; Cioffi, N. Metal nanoantimicrobials for textile applications. Nanotechnol. Rev. 2013, 2. [CrossRef] 
26. González-Henríquez, C.M.; Sarabia-Vallejos, M.A.; Rodriguez-Hernandez, J. Advances in the Fabrication of Antimicrobial Hydrogels for Biomedical Applications. Materials 2017, 10, 232. [CrossRef]

27. Vijayakumar, S.; Saravanakumar, K.; Malaikozhundan, B.; Divya, M.; Vaseeharan, B.; Durán-Lara, E.F.; Wang, M.H. Biopolymer K-carrageenan wrapped $\mathrm{ZnO}$ nanoparticles as drug delivery vehicles for anti MRSA therapy. Int. J. Biol. Macromol. 2020, 144, 9-18. [CrossRef]

28. Yadav, S.; Mehrotra, G.K.; Dutta, P.K. Chitosan based ZnO nanoparticles loaded gallic-acid films for active food packaging. Food Chem. 2021, 334, 127605. [CrossRef]

29. Banerjee, D.; Shivapriya, P.M.; Gautam, P.K.; Misra, K.; Sahoo, A.K.; Samanta, S.K. A Review on Basic Biology of Bacterial Biofilm Infections and Their Treatments by Nanotechnology-Based Approaches. Proc. Natl. Acad. Sci. India Sect. B Biol. Sci. 2020, 90, 243-259. [CrossRef]

30. Sharma, D.; Misba, L.; Khan, A.U. Antibiotics versus biofilm: An emerging battleground in microbial communities. Antimicrob. Resist. Infect. Control 2019, 8, 76. [CrossRef]

31. Canta, M.; Cauda, V. The investigation of the parameters affecting the $\mathrm{ZnO}$ nanoparticle cytotoxicity behaviour: A tutorial review. Biomater. Sci. 2020, 8, 6157-6174. [CrossRef] [PubMed]

32. $\mathrm{Mu}$, Q.; David, C.A.; Galceran, J.; Rey-Castro, C.; Krzemiński, L.; Wallace, R.; Bamiduro, F.; Milne, S.J.; Hondow, N.S.; Brydson, R.; et al. Systematic investigation of the physicochemical factors that contribute to the toxicity of ZnO nanoparticles. Chem. Res. Toxicol. 2014, 27, 558-567. [CrossRef] [PubMed]

33. Pomastowski, P.; Król-Górniak, A.; Railean-Plugaru, V.; Buszewski, B. Zinc Oxide Nanocomposites-Extracellular Synthesis, Physicochemical Characterization and Antibacterial Potential. Materials 2020, 13, 4347. [CrossRef] [PubMed]

34. Hao, N.; Zhang, M.; Zhang, J.X.J. Microfluidics for ZnO micro-/nanomaterials development: Rational design, controllable synthesis, and on-chip bioapplications. Biomater. Sci. 2020, 8, 1783-1801. [CrossRef]

35. Nikam, A.V.; Prasad, B.L.V.; Kulkarni, A.A. Wet chemical synthesis of metal oxide nanoparticles: A review. CrystEngComm 2018, 20, 5091-5107. [CrossRef]

36. Thakur, V.; Verma, U.P.; Rajaram, P. Wet chemical synthesis of ZnO nanocrystals: Dependence of growth and morphology on the solvent composition. J. Mater. Sci. Mater. Electron. 2014, 25, 3242-3250. [CrossRef]

37. Bandeira, M.; Giovanela, M.; Roesch-Ely, M.; Devine, D.M.; da Silva Crespo, J. Green synthesis of zinc oxide nanoparticles: A review of the synthesis methodology and mechanism of formation. Sustain. Chem. Pharm. 2020, 15, 100223. [CrossRef]

38. Liu, Y.; Jiang, X. Why microfluidics? Merits and trends in chemical synthesis. Lab Chip 2017, 17, 3960-3978. [CrossRef]

39. Balucani, M.; Nenzi, P.; Chubenko, E.; Klyshko, A.; Bondarenko, V. Electrochemical and hydrothermal deposition of ZnO on silicon: From continuous films to nanocrystals. J. Nanopart. Res. 2011, 13, 5985-5997. [CrossRef]

40. Kumar, M.; Sasikumar, C. Electrodeposition of Nanostructured ZnO Thin Film: A Review. Am. J. Mater. Sci. Eng. 2014, 2, 18-23. [CrossRef]

41. Izzi, M.; Sportelli, M.C.; Ditaranto, N.; Picca, R.A.; Innocenti, M.; Sabbatini, L.; Cioffi, N. Pros and Cons of Sacrificial Anode Electrolysis for the Preparation of Transition Metal Colloids: A Review. ChemElectroChem 2020, 7, 386-394. [CrossRef]

42. Dierstein, A.; Natter, H.; Meyer, F.; Stephan, H.O.; Kropf, C.; Hempelmann, R. Electrochemical deposition under oxidizing conditions (EDOC): A new synthesis for nanocrystalline metal oxides. Scr. Mater. 2001, 44, 2209-2212. [CrossRef]

43. Natter, H.; Hempelmann, R. Tailor-made nanomaterials designed by electrochemical methods. Electrochim. Acta 2003, 49 , 51-61. [CrossRef]

44. Picca, R.A.; Sportelli, M.C.; Hötger, D.; Manoli, K.; Kranz, C.; Mizaikoff, B.; Torsi, L.; Cioffi, N. Electrosynthesis and characterization of $\mathrm{ZnO}$ nanoparticles as inorganic component in organic thin-film transistor active layers. Electrochim. Acta 2015, 178, 45-54. [CrossRef]

45. Sportelli, M.C.; Picca, R.A.; Izzi, M.; Palazzo, G.; Gristina, R.; Innocenti, M.; Torsi, L.; Cioffi, N. ZnO Nanostructures with Antibacterial Properties Prepared by a Green Electrochemical-Thermal Approach. Nanomaterials 2020, 10, 473. [CrossRef]

46. Jabeera, B.; Anirudhan, T.; Shibli, S.M.A. Nano zinc oxide for efficient activation of aluminium zinc alloy sacrificial anode. J. New Mater. Electrochem. Syst. 2005, 8, 291.

47. Gupta, M.; Tomar, R.S.; Kaushik, S.; Mishra, R.K.; Sharma, D. Effective Antimicrobial Activity of Green ZnO Nano Particles of Catharanthus roseus. Front. Microbiol. 2018, 9. [CrossRef]

48. Shanavas, S.; Duraimurugan, J.; Kumar, G.S.; Ramesh, R.; Acevedo, R.; Anbarasan, P.M.; Maadeswaran, P. Ecofriendly green synthesis of $\mathrm{ZnO}$ nanostructures using Artabotrys Hexapetalu and Bambusa Vulgaris plant extract and investigation on their photocatalytic and antibacterial activity. Mater. Res. Express 2019, 6, 105098. [CrossRef]

49. Alamdari, S.; Sasani Ghamsari, M.; Lee, C.; Han, W.; Park, H.-H.; Tafreshi, M.J.; Afarideh, H.; Ara, M.H.M. Preparation and Characterization of Zinc Oxide Nanoparticles Using Leaf Extract of Sambucus ebulus. Appl. Sci. 2020, 10, 3620. [CrossRef]

50. Bala, N.; Saha, S.; Chakraborty, M.; Maiti, M.; Das, S.; Basu, R.; Nandy, P. Green synthesis of zinc oxide nanoparticles using Hibiscus subdariffa leaf extract: Effect of temperature on synthesis, anti-bacterial activity and anti-diabetic activity. RSC Adv. 2015, 5, 4993-5003. [CrossRef]

51. Borade, P.; Joshi, K.U.; Gokarna, A.; Lerondel, G.; Walke, P.; Late, D.; Jejurikar, S.M. Synthesis and self-assembly of dumbbell shaped $\mathrm{ZnO}$ sub-micron structures using low temperature chemical bath deposition technique. Mater. Chem. Phys. 2016, 169, 152-157. [CrossRef] 
52. Singh, J.; Juneja, S.; Palsaniya, S.; Manna, A.K.; Soni, R.K.; Bhattacharya, J. Evidence of oxygen defects mediated enhanced photocatalytic and antibacterial performance of ZnO nanorods. Colloids Surf. B Biointerfaces 2019, 184, 110541. [CrossRef] [PubMed]

53. Ahmed, F.; Arshi, N.; Jeong, Y.S.; Anwar, M.S.; Dwivedi, S.; Alsharaeh, E.; Koo, B.H. Novel Biomimatic Synthesis of ZnO Nanorods Using Egg White (Albumen) and Their Antibacterial Studies. J. Nanosci. Nanotechnol. 2016, 16, 5959-5965. [CrossRef] [PubMed]

54. Elkady, M.F.; Shokry Hassan, H.; Hafez, E.E.; Fouad, A. Construction of Zinc Oxide into Different Morphological Structures to Be Utilized as Antimicrobial Agent against Multidrug Resistant Bacteria. Bioinorg. Chem. Appl. 2015, 2015, 536854. [CrossRef]

55. de Dicastillo, C.L.; Vidal, C.P.; Falcó, I.; Sánchez, G.; Márquez, P.; Escrig, J. Antimicrobial Bilayer Nanocomposites Based on the Incorporation of As-Synthetized Hollow Zinc Oxide Nanotubes. Nanomaterials 2020, 10, 503. [CrossRef]

56. Chandra, H.; Patel, D.; Kumari, P.; Jangwan, J.S.; Yadav, S. Phyto-mediated synthesis of zinc oxide nanoparticles of Berberis aristata: Characterization, antioxidant activity and antibacterial activity with special reference to urinary tract pathogens. Mater. Sci. Eng. C 2019, 102, 212-220. [CrossRef]

57. Ali, A.; Ambreen, S.; Javed, R.; Tabassum, S.; ul Haq, I.; Zia, M. ZnO nanostructure fabrication in different solvents transforms physio-chemical, biological and photodegradable properties. Mater. Sci. Eng. C 2017, 74, 137-145. [CrossRef]

58. Pasquet, J.; Chevalier, Y.; Couval, E.; Bouvier, D.; Noizet, G.; Morlière, C.; Bolzinger, M.-A. Antimicrobial activity of zinc oxide particles on five micro-organisms of the Challenge Tests related to their physicochemical properties. Int. J. Pharm. 2014, 460, 92-100. [CrossRef]

59. Khan, M.F.; Hameedullah, M.; Ansari, A.H.; Ahmad, E.; Lohani, M.B.; Khan, R.H.; Alam, M.M.; Khan, W.; Husain, F.M.; Ahmad, I. Flower-shaped $\mathrm{ZnO}$ nanoparticles synthesized by a novel approach at near-room temperatures with antibacterial and antifungal properties. Int. J. Nanomed. 2014, 9, 853-864. [CrossRef]

60. Quek, J.A.; Lam, S.M.; Sin, J.C.; Mohamed, A.R. Visible light responsive flower-like ZnO in photocatalytic antibacterial mechanism towards Enterococcus faecalis and Micrococcus luteus. J. Photochem. Photobiol. B Biol. 2018, 187, 66-75. [CrossRef]

61. Talebian, N.; Amininezhad, S.M.; Doudi, M. Controllable synthesis of ZnO nanoparticles and their morphology-dependent antibacterial and optical properties. J. Photochem. Photobiol. B Biol. 2013, 120, 66-73. [CrossRef] [PubMed]

62. Mousa, M.; Khairy, M. Synthesis of nano-zinc oxide with different morphologies and its application on fabrics for UV protection and microbe-resistant defense clothing. Text. Res. J. 2020, 90, 2492-2503. [CrossRef]

63. Mahalakshmi, S.; Hema, N.; Vijaya, P.P. In Vitro Biocompatibility and Antimicrobial activities of Zinc Oxide Nanoparticles (ZnO NPs) Prepared by Chemical and Green Synthetic Route-A Comparative Study. BioNanoScience 2020, 10, 112-121. [CrossRef]

64. Auría-Soro, C.; Nesma, T.; Juanes-Velasco, P.; Landeira-Viñuela, A.; Fidalgo-Gomez, H.; Acebes-Fernandez, V.; Gongora, R.; Almendral Parra, M.J.; Manzano-Roman, R.; Fuentes, M.; et al. Interactions of Nanoparticles and Biosystems: Microenvironment of Nanoparticles and Biomolecules in Nanomedicine. Nanomaterials 2019, 9, 1365.

65. Gharpure, S.; Ankamwar, B. Synthesis and Antimicrobial Properties of Zinc Oxide Nanoparticles. J. Nanosci. Nanotechnol. 2020, 20, 5977-5996. [CrossRef]

66. Espitia, P.J.P.; Soares, N.d.F.F.; Coimbra, J.S.d.R.; de Andrade, N.J.; Cruz, R.S.; Medeiros, E.A.A. Zinc Oxide Nanoparticles: Synthesis, Antimicrobial Activity and Food Packaging Applications. Food Bioprocess Technol. 2012, 5, 1447-1464. [CrossRef]

67. Cheeseman, S.; Christofferson, A.J.; Kariuki, R.; Cozzolino, D.; Daeneke, T.; Crawford, R.J.; Truong, V.K.; Chapman, J.; Elbourne, A. Antimicrobial Metal Nanomaterials: From Passive to Stimuli-Activated Applications. Adv. Sci. 2020, 7, 1902913. [CrossRef]

68. Lemire, J.A.; Harrison, J.J.; Turner, R.J. Antimicrobial activity of metals: Mechanisms, molecular targets and applications. Nat. Rev. Microbiol. 2013, 11, 371-384. [CrossRef]

69. Ali, A.; Phull, A.-R.; Zia, M. Elemental zinc to zinc nanoparticles: Is ZnO NPs crucial for life? Synthesis, toxicological, and environmental concerns. Nanotechnol. Rev. 2018, 7, 413. [CrossRef]

70. Pasquet, J.; Chevalier, Y.; Pelletier, J.; Couval, E.; Bouvier, D.; Bolzinger, M.-A. The contribution of zinc ions to the antimicrobial activity of zinc oxide. Colloids Surf. A Physicochem. Eng. Asp. 2014, 457, 263-274. [CrossRef]

71. Adhikari, S.; Gupta, R.; Surin, A.; Kumar, T.S.; Chakraborty, S.; Sarkar, D.; Madras, G. Visible light assisted improved photocatalytic activity of combustion synthesized spongy-ZnO towards dye degradation and bacterial inactivation. RSC Adv. 2016, 6, 80086-80098. [CrossRef]

72. Kaliraj, L.; Ahn, J.C.; Rupa, E.J.; Abid, S.; Lu, J.; Yang, D.C. Synthesis of panos extract mediated ZnO nano-flowers as photocatalyst for industrial dye degradation by UV illumination. J. Photochem. Photobiol. B Biol. 2019, 199, 111588. [CrossRef] [PubMed]

73. Hajipour, M.J.; Fromm, K.M.; Akbar Ashkarran, A.; de Aberasturi, D.J.; Larramendi, I.R.d.; Rojo, T.; Serpooshan, V.; Parak, W.J.; Mahmoudi, M. Antibacterial properties of nanoparticles. Trends Biotechnol. 2012, 30, 499-511. [CrossRef] [PubMed]

74. Lakshmi Prasanna, V.; Vijayaraghavan, R. Insight into the Mechanism of Antibacterial Activity of ZnO: Surface Defects Mediated Reactive Oxygen Species Even in the Dark. Langmuir 2015, 31, 9155-9162. [CrossRef] [PubMed]

75. Li, Y.; Fu, Z.-Y.; Su, B.-L. Hierarchically Structured Porous Materials for Energy Conversion and Storage. Adv. Funct. Mater. 2012, 22, 4634-4667. [CrossRef]

76. Picone, A.; Riva, M.; Brambilla, A.; Calloni, A.; Bussetti, G.; Finazzi, M.; Ciccacci, F.; Duò, L. Reactive metal-oxide interfaces: A microscopic view. Surf. Sci. Rep. 2016, 71, 32-76. [CrossRef]

77. Eleraky, N.E.; Allam, A.; Hassan, S.B.; Omar, M.M. Nanomedicine Fight against Antibacterial Resistance: An Overview of the Recent Pharmaceutical Innovations. Pharmaceutics 2020, 12, 142. [CrossRef] 
78. Wahid, F.; Zhong, C.; Wang, H.S.; Hu, X.H.; Chu, L.Q. Recent Advances in Antimicrobial Hydrogels Containing Metal Ions and Metals/Metal Oxide Nanoparticles. Polymers 2017, 9. [CrossRef]

79. Farzana, R.; Iqra, P.; Shafaq, F.; Sumaira, S.; Zkia, K.; Hunaiza, T.; Husna, M. Antimicrobial Behavior of Zinc Oxide Nanoparticles and $\beta$-Lactam Antibiotics against Pathogenic Bacteria. Arch. Clin. Microbiol. 2017, 8, 57.

80. Azizi-Lalabadi, M.; Ehsani, A.; Divband, B.; Alizadeh-Sani, M. Antimicrobial activity of Titanium dioxide and Zinc oxide nanoparticles supported in 4A zeolite and evaluation the morphological characteristic. Sci. Rep. 2019, 9, 17439. [CrossRef]

81. Bednář, J.; Svoboda, L.; Rybková, Z.; Dvorský, R.; Malachová, K.; Stachurová, T.; Matýsek, D.; Foldyna, V. Antimicrobial Synergistic Effect Between $\mathrm{Ag}$ and $\mathrm{Zn}$ in $\mathrm{Ag}-\mathrm{ZnO} \cdot \mathrm{mSiO}_{2}$ Silicate Composite with High Specific Surface Area. Nanomaterials 2019, 9, 1265. [CrossRef] [PubMed]

82. Al-Nabulsi, A.; Osaili, T.; Sawalha, A.; Olaimat, A.N.; Albiss, B.A.; Mehyar, G.; Ayyash, M.; Holley, R. Antimicrobial activity of chitosan coating containing $\mathrm{ZnO}$ nanoparticles against $E$. coli $\mathrm{O} 157: \mathrm{H} 7$ on the surface of white brined cheese. Int. J. Food Microbiol. 2020, 334, 108838. [CrossRef] [PubMed]

83. Turlybekuly, A.; Pogrebnjak, A.D.; Sukhodub, L.F.; Sukhodub, L.B.; Kistaubayeva, A.S.; Savitskaya, I.S.; Shokatayeva, D.H.; Bondar, O.V.; Shaimardanov, Z.K.; Plotnikov, S.V.; et al. Synthesis, characterization, in vitro biocompatibility and antibacterial properties study of nanocomposite materials based on hydroxyapatite-biphasic ZnO micro- and nanoparticles embedded in Alginate matrix. Mater. Sci. Eng. C 2019, 104, 109965. [CrossRef] [PubMed]

84. Kulshrestha, S.; Khan, S.; Meena, R.; Singh, B.R.; Khan, A.U. A graphene/zinc oxide nanocomposite film protects dental implant surfaces against cariogenic Streptococcus mutans. Biofouling 2014, 30, 1281-1294. [CrossRef] [PubMed]

85. Oves, M.; Rauf, M.A.; Ansari, M.O.; Aslam Parwaz Khan, A.; Qari, H.A.; Alajmi, M.F.; Sau, S.; Iyer, A.K. Graphene Decorated Zinc Oxide and Curcumin to Disinfect the Methicillin-Resistant Staphylococcus aureus. Nanomaterials 2020, 10, 1004. [CrossRef]

86. Dharmalingam, P.; Jp, P.; Sundararajan, V.; Veluswamy, P.; Chelliah, R.; Samal, D.; Oh, D.-H.; Sahabudeen, S.M.; Venkatasubbu, D Mechanism of inhibition of graphene oxide/zinc oxide nanocomposite against wound infection causing pathogens. Appl. Nanosci. 2019, 10. [CrossRef]

87. Wang, Y.-W.; Cao, A.; Jiang, Y.; Zhang, X.; Liu, J.-H.; Liu, Y.; Wang, H. Superior Antibacterial Activity of Zinc Oxide/Graphene Oxide Composites Originating from High Zinc Concentration Localized around Bacteria. ACS Appl. Mater. Interfaces 2014, 6, 2791-2798. [CrossRef]

88. Valenzuela, L.; Iglesias-Juez, A.; Bachiller-Baeza, B.; Faraldos, M.; Bahamonde, A.; Rosal, R. Biocide mechanism of highly efficient and stable antimicrobial surfaces based on zinc oxide-reduced graphene oxide photocatalytic coatings. J. Mater. Chem. B 2020, 8 , 8294-8304. [CrossRef]

89. Fakhroueian, Z.; Harsini, F.; Chalabian, F.; Katouzian, F.; Shafiekhani, A.; Esmaeilzadeh, P. Influence of Modified ZnO Quantum Dots and Nanostructures as New Antibacterials. Adv. Nanopart. 2013, 2, 247-258. [CrossRef]

90. Singh, A.K.; Pal, P.; Gupta, V.; Yadav, T.P.; Gupta, V.; Singh, S.P. Green synthesis, characterization and antimicrobial activity of zinc oxide quantum dots using Eclipta alba. Mater. Chem. Phys. 2018, 203, 40-48. [CrossRef]

91. Kumar, S.; Mudai, A.; Roy, B.; Basumatary, I.B.; Mukherjee, A.; Dutta, J. Biodegradable Hybrid Nanocomposite of Chitosan/Gelatin and Green Synthesized Zinc Oxide Nanoparticles for Food Packaging. Foods 2020, 9, 1143. [CrossRef] [PubMed]

92. Madhumitha, G.; Elango, G.; Roopan, S.M. Biotechnological aspects of ZnO nanoparticles: Overview on synthesis and its applications. Appl. Microbiol. Biotechnol. 2016, 100, 571-581. [CrossRef] [PubMed]

93. Gold, K.; Slay, B.; Knackstedt, M.; Gaharwar, A.K. Antimicrobial Activity of Metal and Metal-Oxide Based Nanoparticles. Adv. Ther. 2018, 1, 1700033. [CrossRef]

94. Melchionna, M.; Prato, M.; Fornasiero, P. Mix and match metal oxides and nanocarbons for new photocatalytic frontiers. Catal. Today 2016. [CrossRef]

95. Agelidis, A.; Koujah, L.; Suryawanshi, R.; Yadavalli, T.; Mishra, Y.K.; Adelung, R.; Shukla, D. An Intra-Vaginal Zinc Oxide Tetrapod Nanoparticles (ZOTEN) and Genital Herpesvirus Cocktail Can Provide a Novel Platform for Live Virus Vaccine. Front. Immunol. 2019, 10. [CrossRef] [PubMed]

96. Kadiyala, U.; Turali-Emre, E.S.; Bahng, J.H.; Kotov, N.A.; VanEpps, J.S. Unexpected insights into antibacterial activity of zinc oxide nanoparticles against methicillin resistant Staphylococcus aureus (MRSA). Nanoscale 2018, 10, 4927-4939. [CrossRef] [PubMed]

97. Rago, I.; Chandraiahgari, C.R.; Bracciale, M.P.; De Bellis, G.; Zanni, E.; Cestelli Guidi, M.; Sali, D.; Broggi, A.; Palleschi, C.; Sarto, M.S.; et al. Zinc oxide microrods and nanorods: Different antibacterial activity and their mode of action against Gram-positive bacteria. RSC Adv. 2014, 4, 56031-56040. [CrossRef]

98. Yi, G.-C.; Wang, C.; Park, W. ZnO Nanorods: Synthesis, Characterization and Applications. Semicond. Sci. Technol. 2005, 20, 22-34. [CrossRef]

99. Reddy, L.S.; Nisha, M.M.; Joice, M.; Shilpa, P.N. Antimicrobial activity of zinc oxide (ZnO) nanoparticle against Klebsiella pneumoniae. Pharm. Biol. 2014, 52, 1388-1397. [CrossRef]

100. Taghizadeh, S.-M.; Lal, N.; Ebrahiminezhad, A.; Moeini, F.; Seifan, M.; Ghasemi, Y.; Berenjian, A. Green and Economic Fabrication of Zinc Oxide (ZnO) Nanorods as a Broadband UV Blocker and Antimicrobial Agent. Nanomaterials 2020, 10, 530. [CrossRef]

101. Sharma, S.; Naik, D.; Agarwala, V. Synthesis, Characterization and Antibacterial Activity of ZnO Nanoparticles of Different Morphology. Adv. Mater. Res. 2012, 585, 154-158. [CrossRef]

102. Ali, S.G.; Ansari, M.A.; Alzohairy, M.A.; Alomary, M.N.; Jalal, M.; AlYahya, S.; Asiri, S.M.M.; Khan, H.M. Effect of Biosynthesized ZnO Nanoparticles on Multi-Drug Resistant Pseudomonas Aeruginosa. Antibiotics 2020, 9, 260. [CrossRef] [PubMed] 
103. Mishra, Y.K.; Modi, G.; Cretu, V.; Postica, V.; Lupan, O.; Reimer, T.; Paulowicz, I.; Hrkac, V.; Benecke, W.; Kienle, L.; et al. Direct Growth of Freestanding ZnO Tetrapod Networks for Multifunctional Applications in Photocatalysis, UV Photodetection, and Gas Sensing. ACS Appl. Mater. Interfaces 2015, 7, 14303-14316. [CrossRef] [PubMed]

104. Jeyabharathi, S.; Mahalakshmi, R.; Chandramohan, S.; Naveenkumar, S.; Sundar, K.; Muthukumaran, A. Self-assembled hollow ZnO nano and micro donut shape by starch and its antimicrobial potentials. Mater. Lett. 2020, 275, 128128. [CrossRef]

105. Ashajyothi, C.; Harish, K.H.; Dubey, N.; Chandrakanth, R.K. Antibiofilm activity of biogenic copper and zinc oxide nanoparticlesantimicrobials collegiate against multiple drug resistant bacteria: A nanoscale approach. J. Nanostruct. Chem. 2016, 6, 329-341. [CrossRef]

106. Sharma, N.; Singh, V.; Pandey, A.K.; Mishra, B.N.; Kulsoom, M.; Dasgupta, N.; Khan, S.; El-Enshasy, H.A.; Haque, S. Preparation and Evaluation of the ZnO NP-Ampicillin/Sulbactam Nanoantibiotic: Optimization of Formulation Variables Using RSM Coupled GA Method and Antibacterial Activities. Biomolecules 2019, 9, 764. [CrossRef]

107. Eftekhar, B.; Moghimipour, E.; Jahandideh, P.P.; Jalali, S.; Mahmoudian, M. Analgesic effect of odontopaste and a compound intracanal medicament between root canal therapy appointments. Jundishapur J. Nat. Pharm. Prod. 2013, 8, 169-174. [CrossRef]

108. Koch, T.; Peutzfeldt, A.; Malinovskii, V.; Flury, S.; Häner, R.; Lussi, A. Temporary zinc oxide-eugenol cement: Eugenol quantity in dentin and bond strength of resin composite. Eur. J. Oral Sci. 2013, 121, 363-369. [CrossRef]

109. Panzarini, S.R.; Trevisan, C.L.; Brandini, D.A.; Poi, W.R.; Sonoda, C.K.; Luvizuto, E.R.; Dos Santos, C.L. Intracanal dressing and root canal filling materials in tooth replantation: A literature review. Dent. Traumatol. 2012, 28, 42-48. [CrossRef]

110. Ghorbani, M.; Nezhad-Mokhtari, P.; Ramazani, S. Aloe vera-loaded nanofibrous scaffold based on Zein/Polycaprolactone/Collagen for wound healing. Int. J. Biol. Macromol. 2020, 153, 921-930. [CrossRef]

111. Hamdan, S.; Pastar, I.; Drakulich, S.; Dikici, E.; Tomic-Canic, M.; Deo, S.; Daunert, S. Nanotechnology-Driven Therapeutic Interventions in Wound Healing: Potential Uses and Applications. ACS Cent. Sci. 2017, 3, 163-175. [CrossRef] [PubMed]

112. Ramya, R.; Venkatesan, J.; Kim, S.; Sudha, P.N. Biomedical Applications of Chitosan: An Overview. J. Biomater. Tissue Eng. 2012, 2, 100-111. [CrossRef]

113. Sahariah, P.; Másson, M. Antimicrobial Chitosan and Chitosan Derivatives: A Review of the Structure-Activity Relationship. Biomacromolecules 2017, 18, 3846-3868. [CrossRef] [PubMed]

114. Zhang, J.; Xia, W.; Liu, P.; Cheng, Q.; Tahirou, T.; Gu, W.; Li, B. Chitosan Modification and Pharmaceutical/Biomedical Applications. Mar. Drugs 2010, 8, 1962-1987. [CrossRef]

115. Donnadio, A.; Cardinali, G.; Latterini, L.; Roscini, L.; Ambrogi, V. Nanostructured zinc oxide on silica surface: Preparation, physicochemical characterization and antimicrobial activity. Mater. Sci. Eng. C 2019, 104, 109977. [CrossRef]

116. Mousavi, S.A.; Ghotaslou, R.; Khorramdel, A.; Akbarzadeh, A.; Aeinfar, A. Antibacterial and antifungal impacts of combined silver, zinc oxide, and chitosan nanoparticles within tissue conditioners of complete dentures in vitro. Ir. J. Med Sci. 2020. [CrossRef]

117. Qiu, S.; Zhou, H.; Shen, Z.; Hao, L.; Chen, H.; Zhou, X. Synthesis, characterization, and comparison of antibacterial effects and elucidating the mechanism of $\mathrm{ZnO}, \mathrm{CuO}$ and $\mathrm{CuZnO}$ nanoparticles supported on mesoporous silica SBA-3. RSC Adv. 2020, 10, 2767-2785. [CrossRef]

118. Sophee, S.; Prasad, V.; Srinivas, J.; Aparna, R.; Phani, A. Antibacterial Activity of $\mathrm{TiO}_{2}$ and ZnO Microparticles Combination on Water Polluting Bacteria. J. Green Sci. Technol. 2013, 1. [CrossRef]

119. Predoi, D.; Iconaru, S.L.; Predoi, M.V.; Stan, G.E.; Buton, N. Synthesis, Characterization, and Antimicrobial Activity of MagnesiumDoped Hydroxyapatite Suspensions. Nanomaterials 2019, 9, 1295. [CrossRef]

120. Jose, A.; Sunaja Devi, K.R.; Pinheiro, D.; Lakshmi Narayana, S. Electrochemical synthesis, photodegradation and antibacterial properties of PEG capped zinc oxide nanoparticles. J. Photochem. Photobiol. B Biol. 2018, 187, 25-34. [CrossRef]

121. Mocanu, A.; Isopencu, G.; Busuioc, C.; Popa, O.-M.; Dietrich, P.; Socaciu-Siebert, L. Bacterial cellulose films with ZnO nanoparticles and propolis extracts: Synergistic antimicrobial effect. Sci. Rep. 2019, 9, 17687. [CrossRef] [PubMed]

122. Zhao, S.-W.; Guo, C.-R.; Hu, Y.-Z.; Guo, Y.-R.; Pan, Q.-J. The preparation and antibacterial activity of cellulose/ZnO composite: A review. Open Chem. 2018, 16, 9. [CrossRef]

123. Hewlings, S.J.; Kalman, D.S. Curcumin: A Review of Its Effects on Human Health. Foods 2017, 6, 92. [CrossRef] [PubMed]

124. Perera, W.P.T.D.; Dissanayake, R.K.; Ranatunga, U.I.; Hettiarachchi, N.M.; Perera, K.D.C.; Unagolla, J.M.; De Silva, R.T.; Pahalagedara, L.R. Curcumin loaded zinc oxide nanoparticles for activity-enhanced antibacterial and anticancer applications. RSC Adv. 2020, 10, 30785-30795. [CrossRef]

125. Teh, S.J.; Yeoh, S.L.; Lee, K.M.; Lai, C.W.; Abdul Hamid, S.B.; Thong, K.L. Effect of reduced graphene oxide-hybridized ZnO thin films on the photoinactivation of Staphylococcus aureus and Salmonella enterica serovar Typhi. J. Photochem. Photobiol. B Biol. 2016, 161, 25-33. [CrossRef]

126. Bajpai, S.K.; Thomas, V.; Bajpai, M. Novel Strategy for Synthesis of ZnO Microparticles Loaded Cotton Fabrics and Investigation of their Antibacterial Properties. J. Eng. Fibers Fabr. 2011, 6, 155892501100600310. [CrossRef]

127. Noman, M.T.; Petrů, M. Functional Properties of Sonochemically Synthesized Zinc Oxide Nanoparticles and Cotton Composites. Nanomaterials 2020, 10, 1661. [CrossRef]

128. Salat, M.; Petkova, P.; Hoyo, J.; Perelshtein, I.; Gedanken, A.; Tzanov, T. Durable antimicrobial cotton textiles coated sonochemically with $\mathrm{ZnO}$ nanoparticles embedded in an in-situ enzymatically generated bioadhesive. Carbohydr. Polym. 2018, 189, 198-203. [CrossRef] 
129. Subash, A.A.; Chandramouli, K.V.; Ramachandran, T.; Rajendran, R.; Muthusamy, M. Preparation, characterization, and functional analysis of zinc oxide nanoparticle-coated cotton fabric for antibacterial efficacy. J. Text. Inst. 2012, 103, 298-303. [CrossRef]

130. Yilmaz Atay, H. Antibacterial Activity of Chitosan-Based Systems. Funct. Chitosan 2020. [CrossRef]

131. Jaros, J.; Wilson, C.; Shi, V.Y. Fabric Selection in Atopic Dermatitis: An Evidence-Based Review. Am. J. Clin. Dermatol. 2020, 21, 467-482. [CrossRef] [PubMed]

132. Perinelli, D.R.; Fagioli, L.; Campana, R.; Lam, J.K.W.; Baffone, W.; Palmieri, G.F.; Casettari, L.; Bonacucina, G. Chitosan-based nanosystems and their exploited antimicrobial activity. Eur. J. Pharm. Sci. 2018, 117, 8-20. [CrossRef] [PubMed]

133. Tanpichai, S.; Witayakran, S.; Wootthikanokkhan, J.; Srimarut, Y.; Woraprayote, W.; Malila, Y. Mechanical and antibacterial properties of the chitosan coated cellulose paper for packaging applications: Effects of molecular weight types and concentrations of chitosan. Int. J. Biol. Macromol. 2020, 155, 1510-1519. [CrossRef] [PubMed]

134. Wang, H.; Qian, J.; Ding, F. Emerging Chitosan-Based Films for Food Packaging Applications. J. Agric. Food Chem. 2018, 66, 395-413. [CrossRef]

135. Marpu, S.B.; Benton, E.N. Shining Light on Chitosan: A Review on the Usage of Chitosan for Photonics and Nanomaterials Research. Int. J. Mol. Sci. 2018, 19, 1795. [CrossRef]

136. Karahaliloglu, Z.; Kilicay, E.; Denkbas, E.B. Antibacterial chitosan/silk sericin 3D porous scaffolds as a wound dressing material. Artif. Cells Nanomed. Biotechnol. 2017, 45, 1172-1185. [CrossRef]

137. Javed, R.; Rais, F.; Fatima, H.; Haq, I.U.; Kaleem, M.; Naz, S.S.; Ao, Q. Chitosan encapsulated ZnO nanocomposites: Fabrication, characterization, and functionalization of bio-dental approaches. Mater. Sci. Eng. C Mater. Biol. Appl. 2020, 116, 111184. [CrossRef]

138. Morais, D.S.; Guedes, R.M.; Lopes, M.A. Antimicrobial Approaches for Textiles: From Research to Market. Materials 2016, 9, 498. [CrossRef]

139. Rajendiran, K.; Zhao, Z.; Pei, D.-S.; Fu, A. Antimicrobial Activity and Mechanism of Functionalized Quantum Dots. Polymers 2019, 11, 1670. [CrossRef]

140. Zhang, Z.-Y.; Xiong, H.-M. Photoluminescent ZnO Nanoparticles and Their Biological Applications. Materials 2015, 8, 3101-3127. [CrossRef]

141. Chen, H.; Zhang, M.; Li, B.; Chen, D.; Dong, X.; Wang, Y.; Gu, Y. Versatile antimicrobial peptide-based ZnO quantum dots for in vivo bacteria diagnosis and treatment with high specificity. Biomaterials 2015, 53, 532-544. [CrossRef] [PubMed]

142. Jin, T.; Sun, D.; Su, J.Y.; Zhang, H.; Sue, H.J. Antimicrobial efficacy of zinc oxide quantum dots against Listeria monocytogenes, Salmonella Enteritidis, and Escherichia coli O157:H7. J. Food Sci. 2009, 74, M46-M52. [CrossRef] [PubMed]

143. Gabros, S.; Nessel, T.A.; Zito, P.M. Sunscreens and Photoprotection; StatPearls Publishing LLC.: Treasure Island, FL, USA, 2020.

144. Gao, A.L.; Cole, J.G.; Woolsey, Z.T.; Stoecker, W.V. Structured zinc oxide dressing for secondary intention wounds. J. Wound Care 2017, 26, S30-S36. [CrossRef] [PubMed]

145. Gao, Y.; Han, Y.; Cui, M.; Tey, H.L.; Wang, L.; Xu, C. ZnO nanoparticles as an antimicrobial tissue adhesive for skin wound closure. J. Mater. Chem. B 2017, 5, 4535-4541. [CrossRef]

146. Memarzadeh, K.; Sharili, A.S.; Huang, J.; Rawlinson, S.C.; Allaker, R.P. Nanoparticulate zinc oxide as a coating material for orthopedic and dental implants. J. Biomed. Mater. Res. Part A 2015, 103, 981-989. [CrossRef]

147. Suozzi, K.; Turban, J.; Girardi, M. Cutaneous Photoprotection: A Review of the Current Status and Evolving Strategies. Yale J. Biol. Med. 2020, 93, 55-67.

148. Thompson, C.B.; Wiemken, T.L.; Brown, T.S. Effect of Postoperative Dressing on Excisions Performed on the Leg: A Comparison Between Zinc Oxide Compression Dressings Versus Standard Wound Care. Dermatol. Surg. 2017, 43, 1379-1384. [CrossRef]

149. Bae, J.Y.; Park, S.N. Evaluation of anti-microbial activities of ZnO, citric acid and a mixture of both against Propionibacterium acnes. Int. J. Cosmet. Sci. 2016, 38, 550-557. [CrossRef]

150. Cervantes, J.; Eber, A.E.; Perper, M.; Nascimento, V.M.; Nouri, K.; Keri, J.E. The role of zinc in the treatment of acne: A review of the literature. Dermatol. Ther. 2018, 31. [CrossRef]

151. Chuang, H.-C.; Yang, Y.-T.; Chen, H.-C.; Hwang, Y.-H.; Wu, K.-Y.; Chen, T.-F.; Chen, C.-L.; Jhan, M.-K.; Cheng, T.-J. Acute Effects of Pulmonary Exposure to Zinc Oxide Nanoparticles on the Brain in vivo. Aerosol Air Qual. Res. 2020. [CrossRef]

152. Hadrup, N.; Rahmani, F.; Jacobsen, N.R.; Saber, A.T.; Jackson, P.; Bengtson, S.; Williams, A.; Wallin, H.; Halappanavar, S.; Vogel, $\mathrm{U}$. Acute phase response and inflammation following pulmonary exposure to low doses of zinc oxide nanoparticles in mice. Nanotoxicology 2019, 13, 1275-1292. [CrossRef] [PubMed]

153. Rasmussen, K.; Rauscher, H.; Mech, A.; Riego Sintes, J.; Gilliland, D.; González, M.; Kearns, P.; Moss, K.; Visser, M.; Groenewold, M.; et al. Physico-chemical properties of manufactured nanomaterials-Characterisation and relevant methods. An outlook based on the OECD Testing Programme. Regul. Toxicol. Pharmacol. 2018, 92, 8-28. [CrossRef] [PubMed] 